\title{
Ion Channels and Oxidative Stress as a Potential Link for the Diagnosis or Treatment of Liver Diseases
}

\author{
Ana Ramírez, ${ }^{1}$ Alma Yolanda Vázquez-Sánchez, ${ }^{1}$ \\ Natalia Carrión-Robalino, ${ }^{1,2}$ and Javier Camacho ${ }^{1}$ \\ ${ }^{1}$ Department of Pharmacology, Centro de Investigación y de Estudios Avanzados del Instituto Politécnico Nacional, \\ Avenida Instituto Politécnico Nacional 2508, 07360 Mexico City, DF, Mexico \\ ${ }^{2}$ Departamento de Ciencias de la Vida, Universidad de las Fuerzas Armadas, ESPE, Avenida General Rumiñahui, \\ 171-5-231-B Sangolquí, Ecuador
}

Correspondence should be addressed to Javier Camacho; fcamacho@cinvestav.mx

Received 23 July 2015; Revised 22 October 2015; Accepted 27 October 2015

Academic Editor: Karina R. Gordillo

Copyright (C) 2016 Ana Ramírez et al. This is an open access article distributed under the Creative Commons Attribution License, which permits unrestricted use, distribution, and reproduction in any medium, provided the original work is properly cited.

Oxidative stress results from a disturbed balance between oxidation and antioxidant systems. Reactive oxygen species (ROS) and reactive nitrogen species (RNS) may be either harmful or beneficial to the cells. Ion channels are transmembrane proteins that participate in a large variety of cellular functions and have been implicated in the development of a variety of diseases. A significant amount of the available drugs in the market targets ion channels. These proteins have sulfhydryl groups of cysteine and methionine residues in their structure that can be targeted by ROS and RNS altering channel function including gating and conducting properties, as well as the corresponding signaling pathways associated. The regulation of ion channels by ROS has been suggested to be associated with some pathological conditions including liver diseases. This review focuses on understanding the role and the potential association of ion channels and oxidative stress in liver diseases including fibrosis, alcoholic liver disease, and cancer. The potential association between ion channels and oxidative stress conditions could be used to develop new treatments for major liver diseases.

\section{Introduction}

Reactive oxygen species (ROS) and reactive nitrogen species (RNS) are produced during mitochondrial electron transport or by other enzyme systems comprising several oxidoreductases (such as NADPH oxidase which is critical for the bactericidal action of phagocytes) in all cells types, including hepatocytes $[1,2]$.

ROS play a dual role, because they can be either harmful or beneficial to the cells. The normal physiological ROSmediated processes include cellular growth, cell proliferation and regeneration, apoptosis, and microbial killing by phagocytes [3]. The most relevant ROS in the cell physiology are superoxide anion $\left(\mathrm{O}_{2}{ }^{-\bullet}\right)$, hydroxyl radical $\left({ }^{\circ} \mathrm{OH}\right)$, and hydrogen peroxide $\left(\mathrm{H}_{2} \mathrm{O}_{2}\right)$ while the more common RNS are nitric oxide $(\mathrm{NO})$ and peroxynitrite $\left(\mathrm{ONOO}^{-\bullet}\right)$.
ROS generation is essential to maintain cellular functions and ensure cell survival [4]; this is achieved through the activation of transcription factors, such as NF-kappa-B and hypoxia-inducible-factor- $1 \alpha$ (HIF- $1 \alpha)$. ROS also participate in vascular processes [5] and regulate the activation of the immune system by acting as intermediates for cytokines like tumor necrosis factor (TNF- $\alpha$ ) and interleukin- $1 \beta$ (IL$1 \beta)[6,7]$. However, overproduction of ROS and/or RNS, associated with a failure in the antioxidant system (superoxide dismutase, catalase, and glutathione peroxidase activities [8]), causes cellular oxidative stress that promotes DNA, protein, and lipid damage, triggering the development of several diseases [9-11].

Many oxidative stress-related diseases have been reported since the first introduction of this term in 1985 by Sies [12]. Some of the most studied conditions are neurodegenerative 
diseases (Alzheimer, Parkinson, and others) [13-16], cellular aging [17], cardiovascular diseases (hypercholesterolaemia, heart failure, hypertension, myocardial infarction, ischemia/reperfusion injury, and atherosclerosis) [18-20], and pathologies involving chronic inflammation [21]. However, recent studies have also associated oxidative stress with diabetes mellitus [22], obesity [23], infectious diseases (HCV [24], malaria [25]), epilepsy [26], chronic pain [27, 28], and even preeclampsia [29].

\section{Oxidative Stress and Ion Channels}

Ion channels are multimeric proteins located in the plasma membrane and inner cell compartments forming ion-selective pores that open or close in response to specific stimuli such as membrane potential, ligand-binding, temperature, and mechanical stimuli [30]. ROS and RNS can directly induce posttranslational modification of ion channels leading to oxidation, nitrosylation, and/or nitration of specific amino acid residues (sulfhydryl groups or disulfide linkages involving cysteine residues) or indirectly modulate channel function by affecting the signaling pathways that control gene transcription, trafficking, and turnover [31, 32]. The association of ion channels in oxidative stress-related diseases is reported mostly in cardiovascular $[33,34]$ and neurodegenerative illnesses [35-38]. Multiple studies have reported the involvement of calcium [39-41], potassium [27, 30, 36, $42,43]$, sodium [34], and chloride channels [44, 45] in the development of pathologies where oxidative stress plays a major role (Table 1). Ion channels have been also suggested to be associated with oxidative stress in the liver [32, 46] (Table 2). Next, we will describe some of the most studied plasma membrane and mitochondrial ion channels associated with oxidative stress damage, focusing primarily on their potential participation in liver pathological conditions.

\subsection{Participation of Mitochondrial Ion Channels in Different} Pathologies. Generation of high energy molecules is carried out by the mitochondria electron chain transport; hence a great amount of ROS is generated during this metabolism [47, 48]. Because mitochondria are involved in the defense against ROS and its effects on intracellular redox equilibrium, the study of mitochondria in pathological conditions associated with oxidative stress is fundamental $[49,50]$.

There is a huge diversity of ion channels in both the outer and inner mitochondrial membrane (OMM, IMM). Some of the ion channels located on the outer and inner membrane include voltage dependent anion channel (VDAC), $\mathrm{Ca}^{2+}$ uniporter, permeability transition pore (PTP), calciumactivated potassium channels $\left(\mathrm{K}_{\mathrm{Ca}^{2+}}\right)$, ATP-sensitive potassium channels $\left(\mathrm{K}_{\mathrm{ATP}}\right)$, and inner membrane anion channel (IMAC) [51]. The field of mitochondrial ion channels has recently seen some progress through an integrative approach using genetics, physiology, pharmacology, and cell biology tools, which have helped to elucidate the possible functions of these channels [52]. Some of these ion channels participate in several processes such as apoptosis [53, 54], necrosis, thermogenesis, and volume regulation.
The relevance of mitochondrial ion channel research is observed in numerous studies that have demonstrated its participation in the development of pathological conditions like neurodegenerative $[35,55]$ and cardiac diseases [51, 56-60]. Even though mitochondrial dysfunction is associated with different liver pathologies, such as alcoholic liver diseases (ALD) $[49,50,61,62]$, metabolic syndromes (insulin resistance) [63], and nonalcoholic fatty liver disease (NAFLD) [64], the participation of mitochondrial ion channels in the onset or development of oxidative stress-related liver diseases has not been fully explored.

Nakagawa et al. [65] reported the presence of mitochondrial ATP-sensitive $\mathrm{K}^{+}\left(\right.$mito $\left._{\mathrm{ATP}}\right)$ channels in rat primary hepatocytes. This study demonstrated that diazoxide (a selective opener of mitoK $\mathrm{K}_{\mathrm{ATP}}$ channels) enhanced liver regeneration by keeping a higher ATP content in the liver tissue. They concluded that diazoxide sustains the hepatocytes mitochondrial energetics promoting liver regeneration after partial hepatectomy, which is characterized by the presence of oxidative stress. Indeed, potassium channel openers acting on mitochondria have proved to reduce cell damage observed in ischemia. For instance, the effect of cromakalim and diazoxide on cardioprotection against ischemia-reperfusion injury has been shown [66]. Another study carried out by Shimizu et al. [67] assessed the effect of diazoxide against brain damage after middle cerebral artery occlusion (MCAO) in male Wistar rats. The neurological score was improved in animals treated with diazoxide in comparison with the control group; the effects of diazoxide were prominent in the cerebral cortex. Accordingly, the protective effect was reversed with pretreatment of 5-hydroxydecanoate, a selective blocker of mitoK $\mathrm{K}_{\mathrm{ATP}}$, proving that selective opening of mitoK $\mathrm{ATP}_{\mathrm{P}}$ channel has neuroprotective effects against ischemia-reperfusion injury in the rat brain.

Conductances reported for mitochondrial $\mathrm{K}_{\mathrm{ATP}}$ channels of different cell types are lower than those reported for plasma membrane $\mathrm{K}_{\mathrm{ATP}}$ variants, under the same ionic conditions. Moreover, Szabo and Zoratti [52] mention that smallconductance $\mathrm{Ca}^{2+}$-activated $\mathrm{K}^{+}$channels have conductances compatible with the lower values reported for mitoK $\mathrm{K}_{\mathrm{ATP}}$ channels. Pharmacological approaches have their own complications due to the nonspecific targeting exhibited by some mitoK $_{\text {ATP }}$ inhibitors (5-hydroxydecanoate) and openers (such as diazoxide and cromakalim) which can also act on plasma membrane $\mathrm{K}_{\mathrm{ATP}}$ channels, according to some studies. Activators of $\mathrm{K}_{\mathrm{ATP}}$ and $\mathrm{SK}_{\mathrm{Ca}} / \mathrm{IK}_{\mathrm{Ca}}$ (small-conductance, $\mathrm{SK}_{\mathrm{Ca}}$; and intermediate-conductance $\left(\mathrm{IK}_{\mathrm{Ca}}\right)$ calcium-activated potassium channels) have structural similarities, suggesting the possibility of a pharmacological crossover [52].

Interestingly, mitochondria associated-endoplasmic reticulum membranes (MAMs), which are important for $\mathrm{Ca}^{2+}$, lipid, and metabolite exchange, were investigated by Arruda et al. [63] in the liver. They reported that the reorganization of MAMs in a background of obesity resulted in mitochondrial $\mathrm{Ca}^{2+}$ overload, which compromised mitochondrial oxidative capacity and increased oxidative stress. Even though this study did not address $\mathrm{Ca}^{2+}$ flux in mitochondria, its results indicate that obesity drives an abnormal increase in MAMs formation, along with an alteration in $\mathrm{Ca}^{2+}$ flux from the ER 


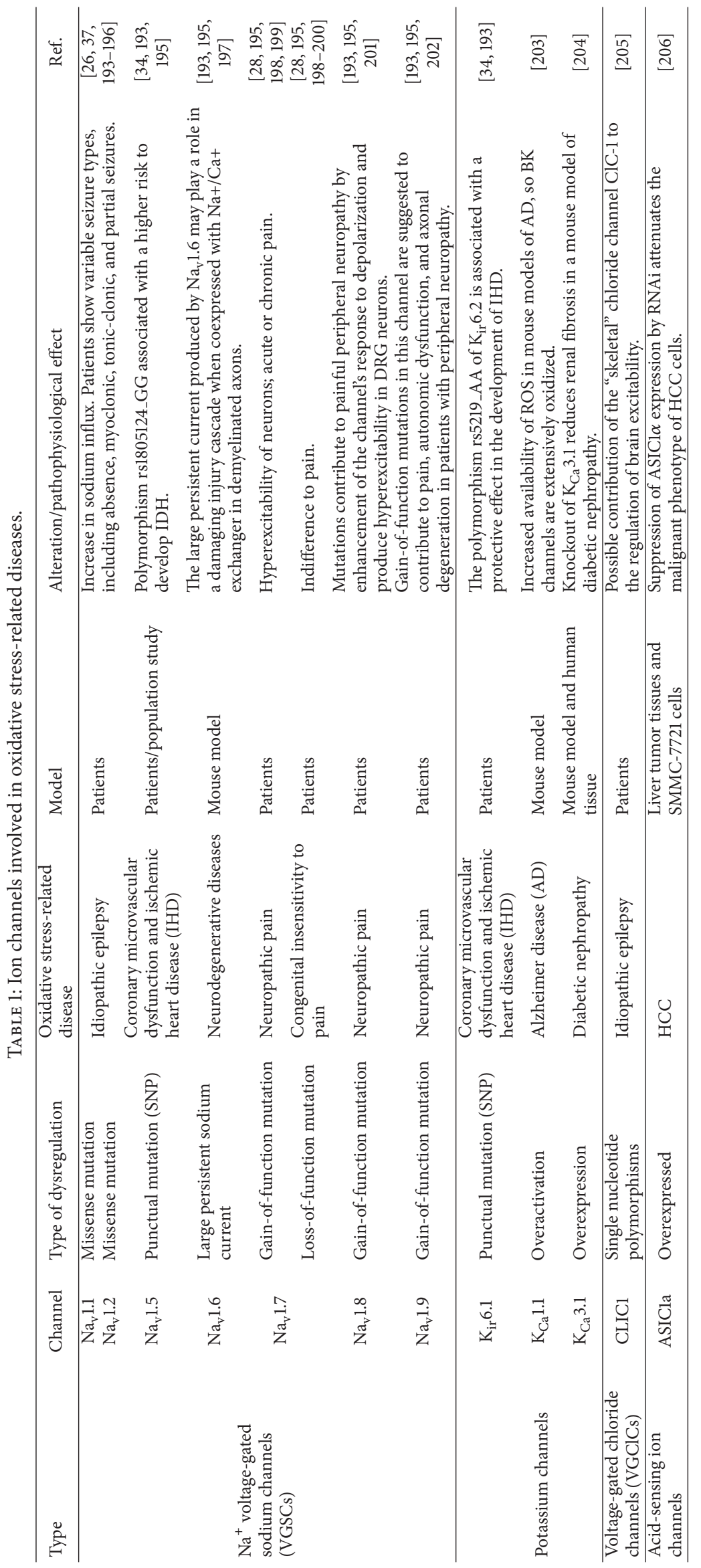


TABLE 2: Ion channels involved in oxidative stress in the liver.

\begin{tabular}{|c|c|c|c|c|}
\hline Ion channel & Pathology & Model & Oxidative stress effect & Reference \\
\hline $\mathrm{K}_{\mathrm{v}} 2.1$ & Hepatoma & Huh-7 cell line & $\begin{array}{l}\mathrm{HCV} \text { inhibits } \mathrm{K}_{\mathrm{v}} 2.1 \text {, suppressing apoptosis in } \\
\text { response to oxidative stress. }\end{array}$ & [24] \\
\hline $\mathrm{K}_{\mathrm{ir}} 6.2$ & Acute liver injury & $\begin{array}{l}\text { LPS-induced mouse model of } \\
\text { liver injury }\end{array}$ & $\begin{array}{l}\mathrm{K}_{\mathrm{ir}} 6.2 \text { knockout exacerbates LPS-induced } \\
\text { endoplasmic reticulum stress in the liver. }\end{array}$ & [207] \\
\hline TRPM2 & $\begin{array}{l}\text { Acetaminophen-induced } \\
\text { liver damage }\end{array}$ & TRPM2 KO mice & $\begin{array}{l}\mathrm{H}_{2} \mathrm{O}_{2}^{-} \text {and acetaminophen-activated } \mathrm{Ca}^{2+} \text { entry } \\
\text { is attenuated in TRPM2 KO mouse hepatocytes. }\end{array}$ & [208] \\
\hline TRPM7 & Liver fibrosis & Rat hepatic stellate cells & $\begin{array}{l}\text { Blockage of TRPM7 causes HSC death induced by } \\
\text { ER stress-mediated apoptosis. }\end{array}$ & {$[138]$} \\
\hline TRPV4 & Liver fibrosis & $\begin{array}{l}\text { Human liver fibrotic tissues } \\
\text { HSC-T6 cells } \\
\text { Rat liver fibrosis model, } \mathrm{CCl}_{4}\end{array}$ & $\begin{array}{l}\text { TRPV4 expression correlates with HSC activation } \\
\text { and in HSC-T } 6 \text { induction of } \alpha \text {-SMA and Coll } \alpha 1 \text {. }\end{array}$ & {$[144]$} \\
\hline $\mathrm{P} 2 \mathrm{Y}$ & Liver fibrosis & Rat liver fibrosis model, $\mathrm{CCl}_{4}$ & $\begin{array}{l}\text { Blockage of } \mathrm{P} 2 \mathrm{Y} \text { receptors inhibited } \mathrm{CCl}_{4} \text {-induced } \\
\text { liver fibrosis in rats. }\end{array}$ & {$[131]$} \\
\hline $\mathrm{P} 2 \mathrm{X} 7$ & $\begin{array}{l}\text { Liver fibrosis } \\
\text { NASH }\end{array}$ & $\begin{array}{l}\text { Mouse liver fibrosis model, } \\
\mathrm{CCL}_{4} \\
\text { Mouse diet-induced obesity } \\
\text { (DIO) }\end{array}$ & $\begin{array}{l}\text { P2X7 blockage attenuates mouse liver fibrosis and } \\
\text { P2X7 gene-deleted mice decreased } \alpha \text {-SMA, } \\
\text { Coll } \alpha 1 \text {, and TGF- } \beta 1 \text { in DIO treated mice. }\end{array}$ & {$[117,133]$} \\
\hline CLIC1 & Hepatocarcinoma & $\begin{array}{l}\text { Mouse hepatocarcinoma } \\
\text { ascites cell line (Hca-F) }\end{array}$ & $\begin{array}{l}\text { Overexpression of CLIC1 contributes to cell } \\
\text { proliferation, apoptosis, migration, and invasion. }\end{array}$ & {$[170]$} \\
\hline ASICla & Liver fibrosis & Rat liver fibrosis model, $\mathrm{CCl}_{4}$ & $\begin{array}{l}\text { ASICla increases in HSC and inhibition of ASICla } \\
\text { suppresses PDGF-induced profibrogenic effects of } \\
\text { activated HSC. }\end{array}$ & {$[160]$} \\
\hline VSOR & Hepatoma & Rat hepatoma (HTC) cells & $\begin{array}{l}\text { Activated by } \mathrm{H}_{2} \mathrm{O}_{2} \text { regulating cell volume and cell } \\
\text { proliferation. }\end{array}$ & {$[170]$} \\
\hline VDAC & Acute ethanol intoxication & Rat primary hepatocytes & $\begin{array}{l}\text { Bax interacts with the PTP component protein } \\
\text { VDAC and likely causes PTP opening, } \\
\text { cytochrome c release, caspase activation, and } \\
\text { apoptosis. }\end{array}$ & [209] \\
\hline
\end{tabular}

to mitochondria. Transient increase in $\mathrm{Ca}^{2+}$ level activates mitochondrial matrix enzymes and stimulates oxidative phosphorylation; thus, a high $\mathrm{Ca}^{2+}$ flux to the mitochondria is detrimental, promoting oxidative metabolism and consequently ROS production [68].

Mitochondrial ion channels are also considered oncological targets due to the fact that cancer transformation involves reprogramming of mitochondrial metabolic and apoptotic functions, which are necessary to ensure proliferation of neoplastic cells and promote metastasis [53, 69-73].

\section{Alcoholic Liver Disease}

Alcohol is a psychoactive substance with dependence-producing properties and is considered a causal risk factor for a broad spectrum of diseases and injury conditions including alcohol dependence, liver cirrhosis, and cancer [74]. Emerging evidence suggests that alcohol consumption is also related to the incidence of infectious diseases such as tuberculosis and HIV/AIDS [74]. Chronic alcohol (ethanol) consumption is a well-reviewed risk factor of liver diseases [75-78]. In fact, at least $15 \%$ of alcoholic cirrhosis cases end up in hepatocellular carcinoma (HCC), the most common type of liver cancer [79], which has one of the highest mortality rates worldwide [80].
Many investigations strongly suggest that liver damage produced by alcohol is mediated through oxidative stress [76, 81-83]. The multistage process observed in ethanol-induced liver diseases (also called alcoholic induced liver diseases (ALD)) covers a broad spectrum of morphological changes from hepatic steatosis (fatty liver), alcoholic hepatitis, chronic hepatitis, and fibrosis ultimately to cirrhosis, which leads to hepatocarcinoma [79]. Ethanol abuse is directly involved in the generation of ROS and RNS that affect the intracellular redox balance within hepatocytes and other cell types in the liver, such as immune cells (neutrophils), sinusoidal endothelial cells (SECs), Kupffer cells (KCs), and hepatic stellate cells (HSCs). Actually, ethanol exposure impairs the structure and function of mitochondria; thus when ROS production is uncontrolled, several responses that promote immune cell activation are triggered [84].

3.1. Ethanol-Induced Oxidative Stress. The liver oxidizes and completely metabolizes alcohol, for which cytosolic and mitochondrial enzymes are required. Ethanol metabolism is carried out through three main pathways involving the following enzymes: alcohol dehydrogenase $(\mathrm{ADH})$ and aldehyde dehydrogenase (ALDH), microsomal ethanol oxidation system (MEOS) via catalysis by cytochrome P450 isoenzymes (2E1, 1A2, and 3A4 isoforms) [85], and catalase. Any type of 
ethanol metabolism will lead to free radical generation that affects the antioxidant defensive system of the cells [86].

Some of the mechanisms by which ethanol impairs the oxidative balance within hepatic cells are acetaldehyde production by $\mathrm{ADH}$, ethanol-induced hypoxia, mitochondria damage, effects on the immune system [87], induction of CYP2E1, mobilization of iron, and alteration of antioxidant enzymes and chemicals [88]. Ethanol metabolism causes depletion of reduced glutathione (GSH) levels and elevates malondialdehyde (MDA), hydroxyethyl radical (HER), and hydroxynonenal (HNE) protein adducts [86], leading to structural and functional abnormalities in the liver. Moreover, alcohol metabolism via CYP2E1 activates stress proteins, promotes endoplasmic reticulum stress, and impairs lysosomal function and autophagy [82]. Additionally, some of the mitochondrial alterations caused by ethanol-induced oxidative stress are DNA damage, ribosomal defects, and inhibition of protein synthesis, which in turn affects the integrity of the electron transport chain (complexes I and II) and the oxidative phosphorylation system that is carried by this organelle $[50,79,89]$.

3.2. Ion Channels in ALD. The association of ion channels in the mechanism of ethanol-induced oxidative stress to the progression of ALD remains elusive and represents a very interesting field of research. The mitochondrial alterations observed under these conditions include the mitochondrial membrane potential and permeability transition (PT) and changes promoting apoptosis [90]. Alteration of mitochondrial membrane potential has been examined in rat hepatocytes exposed to ethanol using rhodamine 123 (Rh123), an indicator of mitochondrial membrane potential. Acute ethanol administration decreased mitochondrial membrane potential in hepatocytes within $30 \mathrm{~min}$, which indicates that mitochondrial alteration is an early event of ethanol-induced hepatocyte injury. Additionally, the increase in PT is induced by opening of the mitochondrial megachannel also known as permeability transition pore (PTP). PTP is regulated by mitochondrial matrix conditions: electrical membrane potential, thiols, oxidants, $\mathrm{pH}$, and calcium concentration; these are factors disturbed as a consequence of ethanol metabolism [91].

Furthermore, Yan et al. [92] evaluated the effect of ethanol on PTP, mitochondrial membrane potential, and intracellular calcium concentration in cultured hepatocytes. Male Wistar rats were administrated intragastrically with alcohol plus olive oil diet; the control group was given an equal amount of normal saline. Ultramicrostructural changes in mitochondria, PTP opening, mitochondrial membrane potential, mitochondrial mass, and intracellular calcium concentration of isolated hepatocytes were measured. The results showed that the mitochondria of the model group had different shapes and that the PTP was disturbed, causing mitochondria swelling. Moreover, mitochondria transmembrane potential was decreased in comparison with the control group. Intracellular calcium concentration was also increased in the liver cells of the group treated with alcohol. These results indicate that ethanol-induced chondriosome injury could be an important early step in ALD pathogenesis.
The molecular nature of PTP is not completely solved. In the last decade findings made by Bernardi and collaborators [93-95] suggested that reconstituted dimers of the $\mathrm{F}_{0} \mathrm{~F}_{1}$ ATP synthase (or complex V) form a channel that exhibits identical properties to those attributed to the mitochondrial megachannel. Indeed, dimers of the ATP synthase treated with $\mathrm{Ca}^{2+}$ generate currents indistinguishable from MMC, while monomers lack any channel activity, strongly suggesting that PTP forms from a specific $\mathrm{Ca}^{2+}$ dependent conformation of the dimers. Moreover, inducers (thiol oxidants, benzodiazepine $(\mathrm{Bz}-423))$ and inhibitors $\left(\mathrm{Mg}^{2+}\right.$, adenine nucleotides) of PTP channel opening have the same effect on ATP synthase. PTP modulators such as membrane potential and matrix $\mathrm{pH}$ also constitute key regulators of the ATP synthase. Open questions remain, and further studies are needed to clarify the effect and mechanism of action of other PTP regulators (e.g., rotenone and quinones) and additional issues concerning the dimer hypothesis. According to these findings, it seems that complex V plays a dual function: ATP synthesis and PTP formation.

PTP participates also in mitochondrial calcium release [96]. Pioneer work established its role regulating mitochondrial $\mathrm{Ca}^{2+}$ homeostasis in hepatocytes. Cyclosporin A (CsA) is a potent inhibitor of prooxidant-induced release of $\mathrm{Ca}^{2+}$ from isolated mitochondria. Pretreatment of hepatocytes with CsA before exposure to prooxidants (tert-butyl hydroperoxide, cumene hydroperoxide, or 3,5-dimethyl- $N$-acetyl$p$-benzoquinone imine) protected hepatocytes from prooxidant injury. This prevented excessive $\mathrm{Ca}^{2+}$ cycling (maintaining mitochondrial $\mathrm{Ca}^{2+}$ pool) that leads to alterations of the transmembrane potential and ATP synthesis and consequently compromises mitochondrial functioning and cell survival [97].

Participation of HSCs in ALD has been proposed in various studies [98-101]. HSCs are located in the space of Disse (the liver space between a hepatocyte and a sinusoid) and these cells participate in the process of ECM remodeling (collagen secretion, etc.) after liver injury. L-type voltageoperated $\mathrm{Ca}^{2+}$ channels (VOCC) regulate calcium entry into the cytoplasm and subsequently cell contraction, which has been well studied in cardiac and smooth muscle cells. HSCs activated by transforming growth factor- $\beta 1$ (TGF- $\beta 1$ ) express VOCC [102], suggesting that voltage-operated $\mathrm{Ca}^{2+}$ channels could also regulate hepatic microcirculation via cell contraction. Itatsu and collaborators [103] evaluated the effect of ethanol on VOCC in HSCs activation. HSCs are known to proliferate in response to liver injury, changing from a "quiescent phenotype" to the "activated phenotype." This study showed that VOCC expression in activated HSCs is significantly increased after 14 days of ethanol exposure in comparison with untreated cells. Ethanol increases the secretion of TGF- $\beta 1$ that also induces ROS production and downregulates antioxidant enzymes, participating in fibrogenesis and tumorigenesis [104]; however the precise link between TGF- $\beta 1$, oxidative stress, and VOCC remains elusive. 


\section{Nonalcoholic Fatty Liver Disease}

Nonalcoholic fatty liver disease (NAFLD) is the most common liver disease reported in western nations. NAFLD prevalence is $30-45 \%$ in Americans. Hispanics have the highest prevalence, followed by Caucasians and African Americans [105]. NAFLD is the accumulation of fat in hepatocytes corresponding to more than $5 \%$ of the liver weight in patients and that is not associated with a significant alcohol consumption (conventionally defined as an ethanol intake $>20$ g/day). The histopathological spectrum includes steatosis (fatty liver) and nonalcoholic steatohepatitis (NASH) which can progress to cirrhosis and finally to hepatocellular carcinoma. NAFLD is associated with the presence of metabolic syndrome. Steatosis is usually associated with a benign prognosis and does not affect overall survival of patients. NASH represents $2-5 \%$ of NAFLD cases and is related to increased mortality $[106,107]$. The pathophysiology of NASH is complex, involving free fatty acid accumulation (fatty liver), hepatic inflammation (cytokine production), and oxidative stress and lipid peroxidation, as well as hepatocellular damage with or without the presence of fibrosis [108]. Oxidative stress triggers necroinflammation in the liver and contributes to the pathogenesis of NASH. ROS generated during fatty acid metabolism in microsomes, peroxisomes, and mitochondria are the main source of oxidative stress [109].

Mitochondrial dysfunction and oxidative stress play an important role in the pathogenesis of NAFLD, observed in rodent models as well as in patients [110, 111]. Increased serum oxidative markers such as thioredoxin, oxidized LDL, and malondialdehyde have been reported in NASH patients. Lipid accumulation within hepatocytes impairs oxidative capacity of the mitochondria, stimulating peroxisomal, and microsomal pathways of fat oxidation, which results in lipotoxicity. Oxidative stress then promotes apoptosis of hepatic cells via ATP, NAD, and glutathione depletion, as well as by DNA, lipid, and protein damage [112].

A few studies on the participation of ion channels in the pathogenesis of NAFLD or NASH have been reported. Recent investigations reported that cation channels may generate calcium signals during endolysosomal fusion and vesicle trafficking. Two-pore channels (TPCs) are cation-selective intracellular ion channels, expressed mostly in the endosomal system (TPC1) and on late endosomes and lysosomes (TPC2). Activation of TPCs mediates calcium release from lysosomal stores. TPC2 leads to trafficking defects, promoting hepatic cholesterol accumulation, hyperlipoproteinaemia, and finally NASH. Grimm et al. [113] explored the role of TPC2 in vitro and in vivo. Embryonic mouse hepatocytes lacking TPC2 displayed a significant impairment of LDL-cholesterol and EGF/EGF-receptor trafficking which can be attributed to a dysfunction of the endolysosomal degradation pathway. TPC2-deficient mice also presented cholesterol overload and liver damage consistent with NAFLD. These results suggest that TPC2 plays an important role in trafficking in the endolysosomal degradation pathway of lipids and is potentially involved in the homeostatic control of various molecules.
NAFLD and obesity are frequently associated between them and are characterized by the formation of protein inclusions and ubiquitinated proteins. Moreover, it has been suggested that autophagy deregulation during obesity contributes to protein inclusion and progression to fatty liver pathologies, such as steatohepatitis and HCC. To elucidate how lipotoxicity and obesity can affect autophagy, an in vitro system in HepG2 cells was established. HepG2 cells cultured with saturated fatty acid exhibited the accumulation of ubiquitinated proteins in soluble inclusion bodies. Increased cytosolic calcium levels in the hepatocytes were observed in an obesity mouse model. The calcium channel blocker verapamil was proven to restore autophagic flux and suppress protein inclusions in both models. Verapamil also reduced hepatic lipid droplet accumulation, insulin resistance, inflammation, and steatohepatitis, which suggest that calcium channel blockers can be used in NAFLD pathologies $[114,115]$.

\section{Fibrosis}

Hepatic fibrosis is characterized by the excessive generation and accumulation of extracellular matrix (ECM) constituents, particularly collagen (types I and III) and fibronectin. Liver fibrosis is a progressive pathology resulting in cirrhosis [116] and ultimately contributes to the development of hepatocellular carcinoma, a malignancy of global importance with very poor prognosis [117]. A fundamental cell event in this process is the activation of HSCs into fibrogenic myofibroblast-like cells which is characterized by the expression of alpha-smooth muscle actin ( $\alpha$-SMA) [118]. Following hepatic injury, HSCs become activated by cytokines and ROS released from KCs, causing HSCs to proliferate, synthesize, and secrete ECM components (Figure 1) [119-121]. Liver fibrogenesis is strongly associated with oxidative stress and it may be the liver disease most frequently related with changes in ion channels. Several studies of ion channels and liver fibrosis are next described.

5.1. Purinergic Receptors. Purinergic receptors have binding sites for nucleotides like ATP and are divided into ligandgated (P2X) and G protein-coupled (P2Y) receptors [122, 123]. Diverse roles of the purinergic signals in the liver have been described in recent years. For example, purinergic receptors are involved in the proliferation [124] and glucose secretion [125] of hepatocytes. They are also related to the secretion [126, 127], proliferation [128], and mechanosensation [129] in cholangiocytes. The first evidence relating purinergic receptor and fibrosis showed the presence of functional P2Y2, P2Y4, and P2Y6 receptors in both quiescent and activated HSCs [130]. Dranoff et al. [131] demonstrated that the administration of pyridoxal-phosphate-6-azophenyl- $2^{\prime}, 4^{\prime}$ disulfonate (PPADS), a synthetic inhibitor of $\mathrm{P} 2 \mathrm{Y}$ receptors, markedly inhibited carbon tetrachloride- $\left(\mathrm{CCl}_{4^{-}}\right)$induced liver fibrosis in rats [131].

One of the most studied channels described in liver fibrosis is P2X7 [132]. Increased mRNA and protein expression of $\mathrm{P} 2 \mathrm{X} 7$ was observed in $\mathrm{CCl}_{4}$-induced liver fibrosis in mice compared with vehicle-treated mice. The competitive P2X7 receptor antagonist A438970 significantly attenuated the 


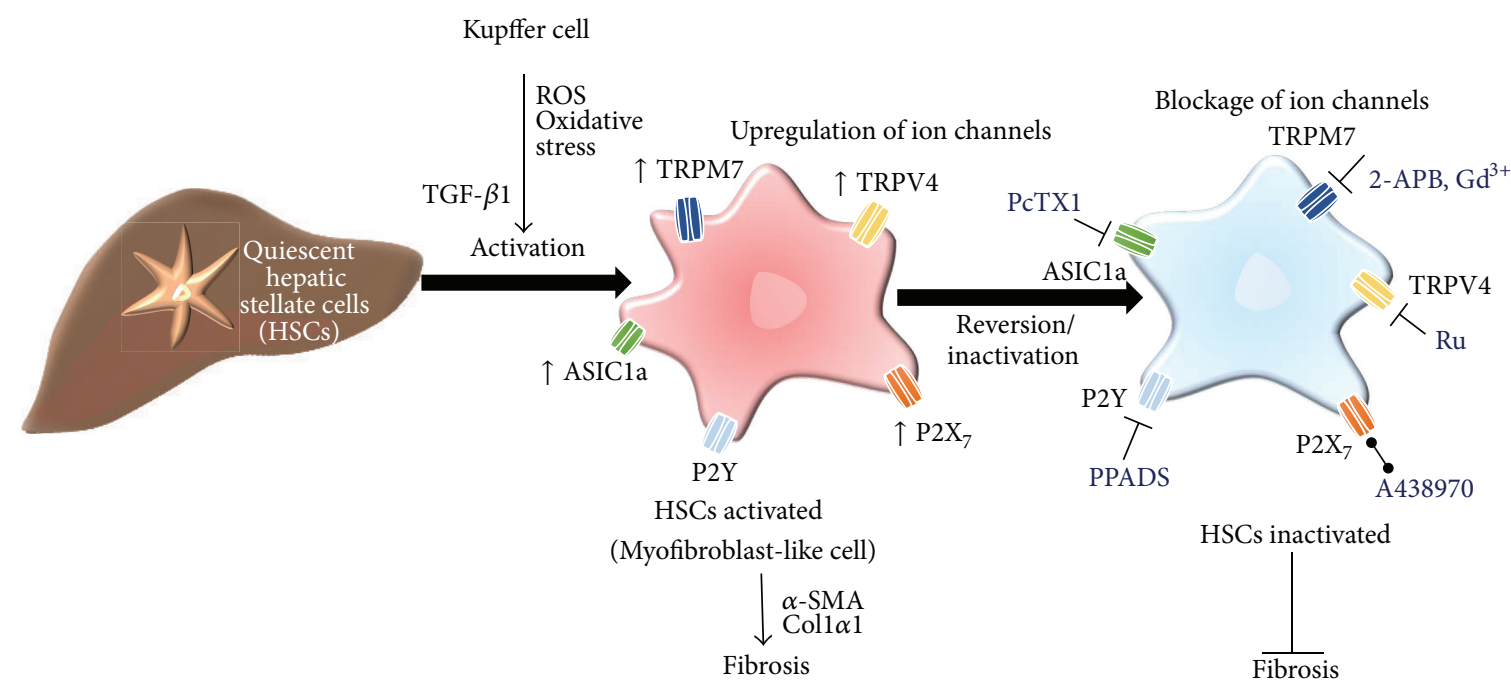

FIgURE 1: Participation of ion channels in HSCs activation during fibrogenesis. Ion channel upregulation including TRPM7, TRPV4, P2X and ASICla has been reported during the activation of HSCs, which is a major event during fibrogenesis. Blocking these channels with pyridoxal-phosphate-6-azophenyl-2', $4^{\prime}$-disulfonate (PPADS), 2-aminoethoxydiphenyl borate (2-APB), and Gd ${ }^{3+} ;$ ruthenium red (Ru); PcTX1 or A438970 reduces proliferation of HSCs and production of profibrotic markers ( $\alpha$-SMA, Coll $\alpha 1)$, preventing the progression of fibrosis.

$\mathrm{CCl}_{4}$-induced necrosis, inflammatory infiltration, and cell injury. The antagonist also reduced collagen accumulation and the production of the proinflammatory mediators TNF- $\alpha$ and IL- $1 \beta$; in addition it inhibited the activity of NF- $\kappa$ B during inflammation as well as protein expression of profibrotic factors including $\alpha$-SMA and TGF- $\beta 1$ [117]. Das et al. [133] demonstrated that mRNA expressions of $\alpha$-SMA, collagen type 1 alpha 1 (Coll $\alpha 1$ ), and TGF- $\beta 1$ were significantly decreased in P2X7 gene-deleted mice compared with wild type mice, suggesting that $\mathrm{P} 2 \mathrm{X} 7$ gene-deleted mice are protected from fibrosis. mRNA expression of P2X receptors in human LX-2, hTERT, and FH11 hepatic stellate cell lines has also been demonstrated [134].

5.2. TRPM7 Channels. Transient receptor potential (TRP) channels are a superfamily of cation channels that play critical roles in detecting environmental changes and stimuli. The TRP melastatin-like 7 (TRPM7) channel is selective mainly for $\mathrm{Ca}^{2+}$ and is involved in sustaining intracellular $\mathrm{Ca}^{2+}$ homeostasis. TRPM7 transcripts are detected in the liver of zebrafish larvae [135] and rat liver [136]. The rat embryonic hepatocyte line RLC-18 expresses a TRPM7-like current suggested to be associated with the proliferation and differentiation of hepatocytes [137]. Likewise, TRPM7 is expressed in HSCs and liver cells from a rat hepatic fibrosis model [138141]. It is also expressed in rat hepatocytes, the rat hepatoma cells WIF-B cells, and a polarized cell line derived from rat hepatoma-human skin fibroblast cross [139], as well as in H4-IIE cells (rat hepatoma cell line) [140]. Particularly, TRPM7 protein was elevated in fibrotic human liver tissues compared with normal liver tissue and the upregulation of the channel strongly correlated with the increasing levels of $\alpha$-SMA and Coll $\alpha 1$ proteins. Additionally, cultured rat HSCT6 cells treated with TGF- $\beta 1$ showed increased expression of
mRNA and protein levels in a time-dependent manner by mechanisms related to the activation of the TGF- $\beta 1 / \mathrm{Smad} 3$ pathway. The elevated channel levels were correlated with the increasing levels of $\alpha$-SMA and Coll $\alpha 1$ proteins [141]. Other studies demonstrated that rat primary HSCs displayed increased TRPM7 expression with different stimuli including TGF- $\beta 1$ or platelet-derived growth factor (PDGF-BB), which are some of the main growth factors stimulating the proliferation of cultured-activated HSCs. This cell proliferation was decreased by the treatment with different TRPM7 nonspecific inhibitors such as 2-aminoethoxydiphenyl borate (2$\mathrm{APB}$ ) and $\mathrm{Gd}^{3+}$. Both inhibitors were able to decrease cell viability in a dose-dependent manner via the activation of the apoptotic pathway $[138,142,143]$ and decreased the expression of $\alpha$-SMA and collagen I. Indeed, the treatment with 2-APB and $\mathrm{Gd}^{3+}$ inhibited TRPM7 protein expression [143]. It has been also suggested that silencing TRPM7 in the activated HSCs may promote collagen degradation by increasing the levels of hepatic matrix metalloproteinases (MMPs) such as MMP-13 and decreasing the levels of tissue inhibitors of metalloproteinases (TIMPs) like TIMP-1 and TIMP-2 expression [141].

5.3. TRPV4. Increased mRNA and protein levels of TRP vanilloid 4 (TRPV4) have been detected in $\mathrm{CCl}_{4}$-treated rat livers and in cultured rat HSC-T6 cells. Additionally, the expression of $\alpha$-SMAD and Coll $\alpha 1$ were elevated according to the progression of HSC-T6 cell activation and correlated with the levels of TRPV4. The blockage of the channel with ruthenium red (a nonspecific TRPV4 channel blocker) or TRPV4 silencing inhibited the proliferation of TGF- $\beta 1$-treated HSCT6 cells and decreased profibrotic marker expression. The TRPV4 expression was directly regulated by miR-203 in TGF$\beta 1$-induced HSCs. Interestingly, increased TRPV4 protein 
expression was found in the liver tissues from liver fibrosis patients compared to normal liver [144].

\subsection{Large Conductance $\mathrm{Ca}^{2+}$ and Voltage-Activated $\mathrm{K}^{+}$Chan-} nels. The large conductance $\mathrm{Ca}^{2+}$ and voltage-activated $\mathrm{K}^{+}$ $\left(\mathrm{K}_{\mathrm{Ca}} 1.1, \mathrm{BK}\right)$ channels are activated by membrane depolarization and/or elevations in intracellular $\mathrm{Ca}^{2+}$ concentration. They are expressed in almost every tissue in the body participating in numerous cellular functions including the regulation of neurotransmitter release and neuronal excitability, relaxation in smooth muscle cells, hormone release in endocrine and exocrine cells, and blood pressure control $[145,146]$. Recently attention has been drawn to BK channels as critical targets of oxidative stress which modifies the gating properties of the channel and is associated with numerous diseases [147], mainly those associated with vascular impair, vascular relaxation, and restricted blood flow [148]. Contraction of smooth vascular cells is given by high elevations of intracellular $\mathrm{Ca}^{2+}$ which makes the plasma membrane permeable to $\mathrm{K}^{+}$ions by activating BK channels which hyperpolarizes the membrane and causes relaxation [149]. The participation of BK channels has been studied in the modulation of the intrahepatic vascular tone in normal and cirrhotic livers using male Wistar rats exposed to $\mathrm{CCL}_{4}$. Cirrhotic livers displayed increased activity of BK channels and blockage of the channel increased the baseline portal perfusion pressure in cirrhotic livers [150]. They also used a vasoconstrictor compound (methoxamine) in combination with a channel opener (NS1619) observing a decrease in the baseline portal perfusion pressure in cirrhotic livers, which indicates the participation of BK channels in the modulation of the intrahepatic vascular tone in cirrhosis. Also, in normal human livers, incubating HSCs with the vasodilator NO (nitric oxide) increases the open probability of BK [151]. ROS have been considered to inhibit vascular BK channels. Tang et al. [152] have found that $\mathrm{H}_{2} \mathrm{O}_{2}$ greatly inhibits $\mathrm{BK}$ channels by oxidizing a single cysteine residue (Cys911) near the intracellular $\mathrm{Ca}^{2+}$ binding site $\left(\mathrm{Ca}^{2+}\right.$ bowl) in the $\mathrm{BK} \alpha$ subunit, disrupting the $\mathrm{Ca}^{2+}$-dependent activation of the channel. These channels have big amounts of cysteines and methionines in their $\alpha$ and $\beta$ subunits [32, 147]; oxidative molecules could cause alterations in these amino acids and therefore impair the channel activity causing important pathophysiological alterations, as it has been seen in vascular relaxation and blood pressure in different diseases.

5.5. Chloride Channels. Chloride channels are ubiquitously expressed and are localized in the plasma membrane and intracellular organelles. These channels participate in cell volume regulation, maintain intracellular $\mathrm{pH}$, and are involved in transepithelial transport, cell cycle, and electrical excitability [153]. Nonspecific chloride channel blockers including 4,4' -diisothiocyanatostilbene-2,2' -disulfonic acid disodium salt hydrate (DIDS), 5-nitro-2-(3-phenylpropylamino)benzoic acid (NPPB), and indanyloxyacetic acid (IAA-94) prevented the increase of intracellular levels of $\mathrm{O}_{2}{ }^{-\bullet}$ and inhibited the activation of the HSC human cell line LX-2, induced by the free radical. These findings suggest that the $\mathrm{O}_{2}^{-\bullet}$ radical may enter through chloride channels producing the HSC activation which is critical to fibrosis development [154]. Other authors, Hawkins et al. [155], have demonstrated that $\mathrm{O}_{2}{ }^{-}$flux across the endothelial cell plasma membrane of immortalized human pulmonary microvascular endothelial cells (HPMVEC) occurs through ClC-3 channels and induces intracellular $\mathrm{Ca}^{2+}$ release, which activates mitochondrial $\mathrm{O}_{2}^{-\bullet}$ production. Also, studies in erythrocytes [156] and amniotic cells [157] have provided evidence for $\mathrm{O}_{2}^{-\bullet}$ transport through anion channels, which could be effectively blocked by DIDS.

5.6. Acid-Sensing Ion Channels. The acid-sensing ion channels (ASICs) are members of the degenerin/epithelial $\mathrm{Na}^{+}$ channel superfamily, which are activated by extracellular protons and induce an amiloride-sensitive cation current $\left(\mathrm{Na}^{+}>\mathrm{Ca}^{2+}>\mathrm{K}^{+}\right)$[158]. The ASICs family is composed of mammals by four different genes encoding seven isoforms: ASICla, ASIC1b, ASIC1b2, ASIC2a, ASIC2b, ASIC3, and ASIC4 [159]. ASICla, which is also permeable to $\mathrm{Ca}^{2+}$, may play a role in liver fibrosis because the channel mediates the activation of HSCs. ASICla is normally expressed in rat liver tissue including primary HSCs, while protein levels were significantly increased in liver fibrosis induced by $\mathrm{CCl}_{4}$ where the channel was mainly expressed in activated HSCs. Furthermore, the protein levels of ASICla increased in a dose- and time-dependent manner in PDGF-activated HSCs while the blockade of ASICla by Psalmotoxin (PcTX1) or the downregulation of the channel by si-RNA reduced the activation of HSCs through the mitogen-activated protein kinases (MAPK) signaling pathway; also ASICla silencing inhibited extracellular-signal-regulated kinases 1 and $2(\mathrm{ERK} 1 / 2)$ and c-Jun N-terminal kinases (JNK) activation [160].

\section{Cancer}

HCC represents $80 \%$ of primary liver cancers; the causes leading to HCC include hepatitis B and hepatitis $C$ virus infection (HBV and HCV, resp.) alcoholism, NASH, and aflatoxin $\mathrm{B}_{1}$ dietary exposure. These factors produce chronic inflammation with severe oxidative stress leading to fibrosis and then cirrhotic livers; this is a common initial mechanism for HCC [161, 162]. Several ion channels have been studied in HCC. Below we summarize recent studies that associate oxidative stress and ion channels in liver carcinogenesis.

6.1. $\mathrm{K}^{+}$Channels. Potassium channels play an important role in various biological processes including cell proliferation, apoptosis, cell volume regulation, and migration and angiogenesis of a variety of carcinoma cells [43]. Different $\mathrm{K}^{+}$channels have been reported to be involved in the pathogenesis of HCC. The intermediate-conductance $\mathrm{Ca}^{2+}$ activated $\mathrm{K}^{+}$ channel 3.1 (IKCal, $\mathrm{K}_{\mathrm{Ca}} 3.1$ ) is overexpressed in HCC tissue [163]. Channel blockade with TRAM-34 inhibited HCC cell proliferation in a time- and dose-dependent manner [163, 164]. TRAM-34 inhibited the activation of NF- $\kappa B$ [164] and activated the MAPK signaling pathway in the SK-Hepl, an invasive liver cell line. The activation of this pathway is linked with the progression of malignant carcinomas 
[165]. $\mathrm{K}^{+}$channels control the membrane potential; thus overexpression in malignant cells is correlated with the progression of the cell cycle from G1 into the S phase, since a transient hyperpolarization is required in this step of the cell cycle. $\mathrm{K}_{\mathrm{Ca}} 3.1$ could maintain the hyperpolarized membrane potential in cancer liver cells, which promotes $\mathrm{Ca}^{2+}$ influx and facilitation of mitogenic activation [166]. Astemizole, a nonspecific inhibitor of $\mathrm{K}_{\mathrm{v}} 10.1$ and $\mathrm{K}_{\mathrm{v}} 11.1$ potassium channels, significantly decreased cell proliferation and increased apoptosis in vitro in the liver cancer cell lines HepG2 and HuH7 [167]. In the same study, the authors observed that astemizole clearly prevented HCC development in vivo. Another recent finding [168] reported that several potassium channels were overexpressed in the liver only in the presence of the chemical carcinogen diethylnitrosamine; when the carcinogen treatment finished, the channel mRNA levels returned almost to normal values. The authors suggested that some potassium channels may serve as carcinogen exposure indicators and that gene expression of the $\mathrm{Abcc} 3$ transporter may serve as a liver tumor marker.

6.2. Chloride Channels. In response to oxidative stress in hepatocarcinoma, two types of chloride channels have been studied, the volume-sensitive outwardly rectifying (VSOR) $\mathrm{Cl}^{-}$channel and chloride intracellular channel 1 (CLIC1). VSOR $\mathrm{Cl}^{-}$channels are ubiquitously expressed in various cell types and are involved in cell volume regulation after osmotic swelling (regulatory volume decrease, RVD); but they also participate in cell proliferation and apoptosis [169]. In rat hepatoma cells (HTC), $\mathrm{H}_{2} \mathrm{O}_{2}$ enhances Src mediated PLC $\gamma 1$ phosphorylation, which subsequently increases intracellular $\mathrm{Ca}^{2+}$ levels that activate $\mathrm{Ca}^{2+}$-sensitive pathways causing VSOR $\mathrm{Cl}^{-}$channel activation [170]; these channels are also activated by $\mathrm{H}_{2} \mathrm{O}_{2}$ in HeLa cells and in both cell lines participate in cell volume regulation and cell proliferation [169]. Thus, activation of VSORs in HTC may provide advantages in the progression of cancer, but further studies are needed to elucidate the potential mechanisms involved. CLIC1 protein has been found to be overexpressed in liver cancer tissues compared to noncancerous liver tissue and significantly correlated with tumor size, metastasis, and poor prognosis [45]. CLIC1 is overexpressed and promotes cell proliferation, migration, and invasion in the mouse hepatocarcinoma ascites cell line Hca-F that has the potential to produce lymphatic metastasis. In accordance, silencing CLIC1 gene expression with shRNA inhibited cell proliferation, induced apoptosis, and decreased migration and invasion [171]. One of the possible mechanisms by which CLIC1 mediates invasion is by regulating maspin (tumor suppressor), matrix metalloproteinases [172], annexin A7, and gelsolin [173].

6.3. T-Type $\mathrm{Ca}^{2+}$ Channels. Oxidative stress induces $\mathrm{Ca}^{2+}$ cytoplasmic increase via calcium influx through plasma membrane channels or calcium release from the endoplasmic reticulum, increasing calcium influx into the mitochondria and nuclei, where different signaling pathways take place in the presence of $\mathrm{Ca}^{2+}$ [174]. T-type calcium channels play a role in cell cycle progression in different types of cancer
$[70,175,176]$. The expression of the three T-type calcium channel subunits was observed in six HCC cell lines (HuH1, PLC/PRF5, SMMC7721, SNU182, SNU449, and SNU475) and in the cell line SNU449 T-type channel blockage with mibefradil decreased cell proliferation [177].

6.4. P2Y Receptor. Extracellular nucleotides, such as ATP, are released from cells in response to various stimuli, such as shear stress, stretching, hypoxia, inflammation, osmotic swelling, and cell death. In HCC cell lines, the levels of $\mathrm{P} 2 \mathrm{Y} 2$ receptor are enhanced compared with human normal hepatocytes; these receptors are involved in ATP-induced $\left[\mathrm{Ca}^{2+}\right]_{\mathrm{i}}$ increase. Silencing P2Y2R expression inhibited ATPinduced human HCC cell proliferation and migration, and, in nude mice that were implanted with human HCC cells, blocking P2Y2R inhibited cell growth [178].

6.5. Hepatitis $C$ Virus. Hepatitis $\mathrm{C}$ virus (HCV) infection is a major health problem worldwide; an estimated 130-170 million people of the world's population are infected with HCV [179]. Most of these individuals (around 80\%) will develop chronic liver disease predisposing them to fibrosis and serious clinical outcomes such as cirrhosis and hepatocellular carcinoma [180]. HCV is an enveloped positivesingle stranded RNA virus whose genome encodes a single polyprotein that produces mature proteins in the host cell: mature viral structural proteins (Core, E1, E2, and possibly p7) and nonstructural proteins (NS2, NS3, NS4A, NS4B, NS5A, and NS5B) [181]. Chronic HCV infection is associated with elevated levels of ROS and RNS leading to an overall increase of oxidative stress within the liver of patients; this redox perturbation has been recognized as a key player in $\mathrm{HCV}$-associated liver diseases. Ion channels have been involved in the development of the redox state in hepatocytes $[182,183]$, but their role in hepatitis $C$ virus infection remains largely unstudied. However, some studies have reported changes in ion channels in the presence of HCV.

6.6. $\mathrm{K}^{+}$Channels. Voltage-gated potassium channels are essential for several cellular processes participating in proliferation, migration, survival, and apoptosis $[184,185]$. In HCV-infected cells, the NS5A viral protein inhibits apoptosis in response to oxidative stress by disrupting the function of the $\mathrm{K}_{\mathrm{v}} 2.1$ channel [24]. In response to oxidative stress, mixed lineage kinase 3 (MLK3) is activated leading to activation of p38-MAPK that phosphorylates $\mathrm{K}_{\mathrm{v}} 2.1$ at a serine residue in the cytoplasmic C terminus (S800), which is then trafficked to the plasma membrane resulting in an outward $\mathrm{K}^{+}$current, which is involved in causing apoptosis. NS5A inhibits MLK3 activation then preventing $\mathrm{K}_{\mathrm{v}} 2.1$ phosphorylation and channel activity in the plasma membrane and avoiding apoptosis [186]. This is advantageous to the infected cells that are able to avoid apoptosis induced by oxidative stress.

6.7. Chloride Channels. Activation of chloride channels is required for the life cycle of HCV; blocking chloride channels inhibits HCV genome replication and reduces NS5A expression [187]. This might occur because $\mathrm{Cl}^{-}$channels are responsible for endosome and lysosomal acidification [153], 
which is necessary to initiate entry fusion of HCV envelope proteins to the membrane and viral genome release [188]. $\mathrm{HCV}$ induces ROS production in liver infected cells and activation of chloride channels may take place to maintain the oxidative state in the infected cells. It has been proposed that when ROS are produced by the NAPDH oxidase, the transfer electrons from the intracellular donor NADPH to extracellular oxygen gives rise to an outward flow of negative charges that depolarizes the plasma membrane in leukocytes. To counteract the more negative potential, the activation of chloride channels may take place modifying the membrane potential and allowing an optimal ROS production $[44,189]$. Thus, HCV-infected cells may balance the loss of negative charges in the cell by activating chloride channels.

6.8. P2X Receptors. P2X receptors regulate proliferation and glucose release in hepatocytes $[125,190]$. Transcripts of P2X1, P2X2, P2X3, P2X4, and P2X7 have been observed in rat liver cells and rat hepatocytes [125]. Huh-7 cells transfected with the HCV proteins E1E2 showed increased P2X4 gene expression in comparison with control Huh-7 cells [191]. P2X4 is one of the most responsive subtypes of $\mathrm{P} 2 \mathrm{X}$ receptors and may participate in mediating glucose-release via glycogenolysis [192].

\section{Conclusions}

Ion channels play an important role in cellular processes associated with oxidative stress in health and disease. These proteins are very important pharmacological targets for several human pathologies. Therefore, more research on the participation of ion channels in oxidative stress-associated liver diseases should help to find new early-detection tools as well as novel therapeutic strategies.

\section{Abbreviations}

ASICs: Acid-sensing ion channels

ANT: Adenine nucleotide translocator

ADH: Alcohol dehydrogenase

ALD: Alcoholic liver diseases

ALDH: Aldehyde dehydrogenase

$\alpha$-SMA: Alpha-smooth muscle actin

2-APB: 2-Aminoethoxydiphenyl borate

Bz-423: 1,4-Benzodiazepine

$\mathrm{K}_{\mathrm{ATP}}$ : ATP-sensitive potassium channels

$\mathrm{K}_{\mathrm{Ca}^{2+}}$ : Calcium-activated potassium channels

$\mathrm{CCl}_{4}$ : Carbon tetrachloride

CLIC1: Chloride intracellular channel 1

Coll $\alpha 1$ : Collagen type 1 alpha 1

CsA: Cyclosporin A

DIDS: Diisothiocyanatostilbene-2, $2^{\prime}$-disulfonic acid disodium salt hydrate

ER: Endoplasmic reticulum

EGF: Epidermal growth factor

ECM: Extracellular matrix

ERK1/2: Extracellular-signal-regulated kinases 1 and 2

P2Y: $\quad$ G protein-coupled purinergic receptors $2 \mathrm{Y}$
HSCs: $\quad$ Hepatic stellate cells

HBV: Hepatitis B virus

HCV: Hepatitis $\mathrm{C}$ virus

HCC: Hepatocellular carcinoma

HTC: Hepatoma cells

HIV/AIDS: Human immunodeficiency virus infection and acquired immune deficiency syndrome

HER: Hydroxyethyl radical

$\mathrm{H}_{2} \mathrm{O}_{2}$ : Hydrogen peroxide

•OH: Hydroxyl radical

HNE: Hydroxynonenal

HIF- $1 \alpha$ : Hypoxia-inducible-factor- $1 \alpha$

IAA-94: Indanyloxyacetic acid

IMAC: $\quad$ Inner membrane anion channel

IMM: $\quad$ Inner mitochondrial membrane

IL-1 $\beta$ : Interleukin-1 $\beta$

$\mathrm{IK}_{\mathrm{Ca}}$ : Intermediate-conductance $\mathrm{Ca}^{2+}$ activated $\mathrm{K}^{+}$channel

JNK: $\quad$ c-Jun N-terminal kinases

KCs: $\quad$ Kupffer cells

$\mathrm{K}_{\mathrm{ATP}}: \quad$ ATP-sensitive $\mathrm{K}^{+}$

P2X: $\quad$ Ligand-gated purinergic receptor

VOCC: L-type voltage-operated $\mathrm{Ca}^{2+}$ channels

MAPK: Mitogen-activated protein kinases

MDA: Malondialdehyde

MMPs: $\quad$ Matrix metalloproteinases

MCAO: Middle cerebral artery occlusion

MAMs: Mitochondria associated-endoplasmic reticulum membranes

mitoK $_{\text {ATP }}$ : Mitochondrial ATP-sensitive $\mathrm{K}^{+}$

MEOS: $\quad$ Microsomal ethanol oxidation system

PT: $\quad$ Permeability transition

MLK3: $\quad$ Mixed lineage kinase 3

NAFLD: Nonalcoholic fatty liver disease

NASH: Nonalcoholic steatohepatitis

NADH: Nicotinamide adenine dinucleotide (reduced)

NO: $\quad$ Nitric oxide

NPPB: 5-Nitro-2-(3-phenylpropylamino)benzoic acid

NF-kappa-B: Nuclear factor kappa-light-chainenhancer of activated B cells

OMM: $\quad$ Outer mitochondrial membrane

PTP: $\quad$ Permeability transition pore

$\mathrm{ONOO}^{-\bullet}$ : Peroxynitrite

PLC $\gamma 1: \quad$ Phospholipase C gamma 1

PDGF-BB: Platelet-derived growth factor

PcTX1: Psalmotoxin

PPADS: Pyridoxal-phosphate-6-azophenyl$2^{\prime}, 4^{\prime}$-disulfonate

ROS: $\quad$ Reactive oxygen species

RNS: $\quad$ Reactive nitrogen species

GSH: Reduced glutathione

RVD: Regulatory volume decrease

Rh123: Rhodamine 123

SECs: $\quad$ Sinusoidal endothelial cells

$\mathrm{SK}_{\mathrm{Ca}}$ : $\quad$ Small-conductance $\mathrm{Ca}^{2+}$ activated $\mathrm{K}^{+}$channel 
$\mathrm{O}_{2}^{-\bullet}: \quad$ Superoxide anion

TIMPs: Tissue inhibitors of metalloproteinases

TGF- $\beta 1$ : Transforming growth factor-beta-1

TRP: $\quad$ Transient receptor potential

TRPM7: Transient receptor potential melastatin-like 7

TRPV4: Transient receptor potential vanilloid 4

TNF- $\alpha$ : Tumor necrosis factor alpha

TPCs: Two-pore channels

VDAC: Voltage dependent anion channel

VSOR: Volume-sensitive outwardly rectifying.

\section{Conflict of Interests}

The authors declare that there is no conflict of interests regarding the publication of this paper.

\section{Acknowledgment}

The liver disease research related to this topic in the laboratory of Dr. Camacho has been partially funded by the Conacyt Grant 168102 to Javier Camacho.

\section{References}

[1] M. Marí, A. Colell, A. Morales, C. Von Montfort, C. GarciaRuiz, and J. C. Fernández-Checa, "Redox control of liver function in health and disease," Antioxidants and Redox Signaling, vol. 12, no. 11, pp. 1295-1331, 2010.

[2] H. J. Forman and M. Torres, "Reactive oxygen species and cell signaling: respiratory burst in macrophage signaling," American Journal of Respiratory and Critical Care Medicine, vol. 166, no. 12, part 2, pp. S4-S8, 2002.

[3] C. Esquivel-Chirino, J. Esquivel-Soto, J. A. Morales-González et al., "Inflammatory environmental, oxidative stress in tumoral progression," in Oxidative Stress and Chronic Degenerative Diseases-A Role for Antioxidants, chapter 8, InTech, Rijeka, Croatia, 2013.

[4] C. Gorrini, I. S. Harris, and T. W. Mak, "Modulation of oxidative stress as an anticancer strategy," Nature Reviews Drug Discovery, vol. 12, no. 12, pp. 931-947, 2013.

[5] M. Y. Lee and K. K. Griendling, "Redox signaling, vascular function, and hypertension," Antioxidants and Redox Signaling, vol. 10, no. 6, pp. 1045-1059, 2008.

[6] B. Poljsak, "Strategies for reducing or preventing the generation of oxidative stress," Oxidative Medicine and Cellular Longevity, vol. 2011, Article ID 194586, 15 pages, 2011.

[7] Z. Durackova, "Some current insights into oxidative stress," Physiological Research, vol. 59, no. 4, pp. 459-469, 2010.

[8] F. Farinati, M. Piciocchi, E. Lavezzo, M. Bortolami, and R. Cardin, "Oxidative stress and inducible nitric oxide synthase induction in carcinogenesis," Digestive Diseases, vol. 28, no. 4-5, pp. 579-584, 2010.

[9] A. A. Alfadda and R. M. Sallam, "Reactive oxygen species in health and disease," Journal of Biomedicine and Biotechnology, vol. 2012, Article ID 936486, 14 pages, 2012.

[10] S. Noori, "An overview of oxidative stress and antioxidant defensive system," Journal of Clinical \& Cellular Immunology, vol. 1 , no. 8, 2012.
[11] A. Rahal, A. Kumar, V. Singh et al., "Oxidative stress, prooxidants, and antioxidants: the interplay," BioMed Research International, vol. 2014, Article ID 761264, 19 pages, 2014.

[12] H. Sies, "Oxidative stress: introductory remarks," in Oxidative Stress, pp. 1-8, Academic Press, London, UK, 1985.

[13] B. Uttara, A. V. Singh, P. Zamboni, and R. T. Mahajan, "Oxidative stress and neurodegenerative diseases: a review of upstream and downstream antioxidant therapeutic options," Current Neuropharmacology, vol. 7, no. 1, pp. 65-74, 2009.

[14] R. Thanan, S. Oikawa, Y. Hiraku et al., "Oxidative stress and its significant roles in neurodegenerative diseases and cancer," International Journal of Molecular Sciences, vol. 16, no. 1, pp. 193217, 2014.

[15] Y. T. Chang, W. Chang, N. Tsai et al., "The roles of biomarkers of oxidative stress and antioxidant in Alzheimer's disease: a systematic review," BioMed Research International, vol. 2014, Article ID 182303, 14 pages, 2014.

[16] C. Henchcliffe and M. F. Beal, "Mitochondrial biology and oxidative stress in Parkinson disease pathogenesis," Nature Clinical Practice Neurology, vol. 4, no. 11, pp. 600-609, 2008.

[17] W. Dröge and H. M. Schipper, "Oxidative stress and aberrant signaling in aging and cognitive decline," Aging Cell, vol. 6, no. 3, pp. 361-370, 2007.

[18] C. Ceconi, A. Boraso, A. Cargnoni, and R. Ferrari, "Oxidative stress in cardiovascular disease: myth or fact?" Archives of Biochemistry and Biophysics, vol. 420, no. 2, pp. 217-221, 2003.

[19] M. Hristova and M. Penev, "Oxidative stress and cardiovascular diseases," Trakia Journal of Science, vol. 12, no. 3, pp. 296-303, 2014.

[20] R. Hutcheson and P. Rocic, "The metabolic syndrome, oxidative stress, environment, and cardiovascular disease: the great exploration," Experimental Diabetes Research, vol. 2012, Article ID 271028, 13 pages, 2012.

[21] S. A. Noeman, H. E. Hamooda, and A. A. Baalash, "Biochemical study of oxidative stress markers in the liver, kidney and heart of high fat diet induced obesity in rats," Diabetology and Metabolic Syndrome, vol. 3, no. 1, article 17, 2011.

[22] A. C. Maritim, R. A. Sanders, and J. B. Watkins III, "Diabetes, oxidative stress, and antioxidants: a review," Journal of Biochemical and Molecular Toxicology, vol. 17, no. 1, pp. 24-38, 2003.

[23] L. Marseglia, S. Manti, G. D’Angelo et al., "Oxidative stress in obesity: a critical component in human diseases," International Journal of Molecular Sciences, vol. 16, no. 1, pp. 378-400, 2014.

[24] J. Mankouri, M. L. Dallas, M. E. Hughes et al., "Suppression of a pro-apoptotic $\mathrm{K}^{+}$channel as a mechanism for hepatitis $\mathrm{C}$ virus persistence," Proceedings of the National Academy of Sciences of the United States of America, vol. 106, no. 37, pp. 15903-15908, 2009.

[25] S. Percário, D. Moreira, B. Gomes et al., "Oxidative stress in malaria," International Journal of Molecular Sciences, vol. 13, no. 12, pp. 16346-16372, 2012.

[26] S. Waldbaum and M. Patel, "Mitochondria, oxidative stress, and temporal lobe epilepsy," Epilepsy Research, vol. 88, no. 1, pp. 2345, 2010.

[27] E. A. Afify, M. M. Khedr, A. G. Omar, and S. A. Nasser, "The involvement of K(ATP) channels in morphine-induced antinociception and hepatic oxidative stress in acute and inflammatory pain in rats," Fundamental and Clinical Pharmacology, vol. 27, no. 6, pp. 623-631, 2013.

[28] S. D. Dib-Hajj, T. R. Cummins, J. A. Black, and S. G. Waxman, "From genes to pain: $\mathrm{Na}_{\mathrm{v}} 1.7$ and human pain disorders," Trends in Neurosciences, vol. 30, no. 11, pp. 555-563, 2007. 
[29] M. Can, B. Guven, S. Bektas, and I. Arikan, "Oxidative stress and apoptosis in preeclampsia," Tissue and Cell, vol. 46, no. 6 , pp. 477-481, 2014.

[30] H. Akbarali, "Oxidative stress and ion channels", in Systems Biology of Free Radicals and Antioxidants, I. Laher, Ed., pp. 355373, Springer, Berlin, Germany, 2014.

[31] L. Annunziato, A. Pannaccione, M. Cataldi et al., "Modulation of ion channels by reactive oxygen and nitrogen species: a pathophysiological role in brain aging?" Neurobiology of Aging, vol. 23, no. 5, pp. 819-834, 2002.

[32] Y. Liu and D. D. Gutterman, "Oxidative stress and potassium channel function," Clinical and Experimental Pharmacology and Physiology, vol. 29, no. 4, pp. 305-311, 2002.

[33] K. Takahashi, Y. Kakimoto, K. Toda, and K. Naruse, "Mechanobiology in cardiac physiology and diseases," Journal of Cellular and Molecular Medicine, vol. 17, no. 2, pp. 225-232, 2013.

[34] F. Fedele, M. Mancone, W. M. Chilian et al., "Role of genetic polymorphisms of ion channels in the pathophysiology of coronary microvascular dysfunction and ischemic heart disease," Basic Research in Cardiology, vol. 108, no. 6, article 387, 2013.

[35] C. Chinopoulos and V. Adam-Vizi, "Calcium, mitochondria and oxidative stress in neuronal pathology. Novel aspects of an enduring theme," The FEBS Journal, vol. 273, no. 3, pp. 433-450, 2006.

[36] F. Sesti, S. Liu, and S.-Q. Cai, "Oxidation of potassium channels by ROS: a general mechanism of aging and neurodegeneration?" Trends in Cell Biology, vol. 20, no. 1, pp. 45-51, 2010.

[37] M. Mantegazza, G. Curia, G. Biagini, D. S. Ragsdale, and M. Avoli, "Voltage-gated sodium channels as therapeutic targets in epilepsy and other neurological disorders," The Lancet Neurology, vol. 9, no. 4, pp. 413-424, 2010.

[38] G. Zündorf and G. Reiser, "Calcium dysregulation and homeostasis of neural calcium in the molecular mechanisms of neurodegenerative diseases provide multiple targets for neuroprotection," Antioxidants and Redox Signaling, vol. 14, no. 7, pp. 1275-1288, 2011.

[39] M. Naziroǧlu, D. Merve Dikici, and Ş. Dursun, "Role of oxidative stress and $\mathrm{Ca}^{2+}$ signaling on molecular pathways of neuropathic pain in diabetes: focus on TRP channels," Neurochemical Research, vol. 37, no. 10, pp. 2065-2075, 2012.

[40] J. Striessnig, A. Pinggera, G. Kaur, G. Bock, and P. Tuluc, "Ltype $\mathrm{Ca}^{2+}$ channels in heart and brain," Wiley Interdisciplinary Reviews: Membrane Transport and Signaling, vol. 3, no. 2, pp. 15-38, 2014.

[41] B. Brawek and O. Garaschuk, "Network-wide dysregulation of calcium homeostasis in Alzheimer's disease," Cell and Tissue Research, vol. 357, no. 2, pp. 427-438, 2014.

[42] J. I. Vandenberg, "Oxidative stress fine-tunes the dance of hERG $\mathrm{K}^{+}$channels," Journal of Physiology, vol. 588, no. 16, pp. 29752975, 2010.

[43] L. A. Pardo and W. Stühmer, "The roles of $\mathrm{K}^{+}$channels in cancer," Nature Reviews Cancer, vol. 14, no. 1, pp. 39-48, 2014.

[44] S. Averaimo, R. H. Milton, M. R. Duchen, and M. Mazzanti, "Chloride intracellular channel 1 (CLIC1): sensor and effector during oxidative stress," FEBS Letters, vol. 584, no. 10, pp. 20762084, 2010.

[45] S. Zhang, X.-M. Wang, Z.-Y. Yin et al., "Chloride intracellular channel 1 is overexpression in hepatic tumor and correlates with a poor prognosis," APMIS, vol. 121, no. 11, pp. 1047-1053, 2013.
[46] F. Simon, D. Varela, and C. Cabello-Verrugio, "Oxidative stressmodulated TRPM ion channels in cell dysfunction and pathological conditions in humans," Cellular Signalling, vol. 25, no. 7, pp. 1614-1624, 2013.

[47] A. Boveris and B. Chance, "The mitochondrial generation of hydrogen peroxide. General properties and effect of hyperbaric oxygen," Biochemical Journal, vol. 134, no. 3, pp. 707-716, 1973.

[48] H. Sies, "Role of metabolic $\mathrm{H}_{2} \mathrm{O}_{2}$ generation: redox signaling and oxidative stress," Journal of Biological Chemistry, vol. 289, no. 13, pp. 8735-8741, 2014.

[49] J. B. Hoek, A. Cahill, and J. G. Pastorino, "Alcohol and mitochondria: a dysfunctional relationship," Gastroenterology, vol. 122, no. 7, pp. 2049-2063, 2002.

[50] S. M. Bailey, "A review of the role of reactive oxygen and nitrogen species in alcohol-induced mitochondrial dysfunction," Free Radical Research, vol. 37, no. 6, pp. 585-596, 2003.

[51] B. O'Rourke, "Pathophysiological and protective roles of mitochondrial ion channels," Journal of Physiology, vol. 529, no. 1, pp. 23-36, 2000.

[52] I. Szabo and M. Zoratti, "Mitochondrial channels: ion fluxes and more," Physiological Reviews, vol. 94, no. 2, pp. 519-608, 2014.

[53] B. O'Rourke, S. Cortassa, and M. A. Aon, "Mitochondrial ion channels: gatekeepers of life and death," Physiology, vol. 20, no. 5, pp. 303-315, 2005.

[54] S.-Y. Ryu, P. M. Peixoto, O. Teijido, L. M. Dejean, and K. W. Kinnally, "Role of mitochondrial ion channels in cell death," BioFactors, vol. 36, no. 4, pp. 255-263, 2010.

[55] A. A. Starkov, C. Chinopoulos, and G. Fiskum, "Mitochondrial calcium and oxidative stress as mediators of ischemic brain injury," Cell Calcium, vol. 36, no. 3-4, pp. 257-264, 2004.

[56] G. J. Grover and K. D. Garlid, "ATP-sensitive potassium channels: a review of their cardioprotective pharmacology," Journal of Molecular and Cellular Cardiology, vol. 32, no. 4, pp. 677-695, 2000.

[57] B. O’Rourke, S. Cortassa, F. Akar, and M. Aon, "Mitochondrial ion channels in cardiac function and dysfunction," Novartis Foundation Symposia, vol. 287, pp. 140-156, 2007.

[58] G. Plank, L. Zhou, J. L. Greenstein et al., "From mitochondrial ion channels to arrhythmias in the heart: computational techniques to bridge the spatio-temporal scales," Philosophical Transactions of the Royal Society of London. Series A. Mathematical, Physical and Engineering Sciences, vol. 366, no. 1879, pp. 3381-3409, 2008.

[59] P. M. Peixoto, S.-Y. Ryu, and K. W. Kinnally, "Mitochondrial ion channels as therapeutic targets," FEBS Letters, vol. 584, no. 10, pp. 2142-2152, 2010.

[60] H. Nishida, A. Matsumoto, N. Tomono, T. Hanakai, S. Harada, and H. Nakaya, "Biochemistry and physiology of mitochondrial ion channels involved in cardioprotection," FEBS Letters, vol. 584, no. 10, pp. 2161-2166, 2010.

[61] F. Nassir and J. A. Ibdah, "Role of mitochondria in alcoholic liver disease," World Journal of Gastroenterology, vol. 20, no. 9, pp. 2136-2142, 2014.

[62] S. M. Bailey and C. C. Cunningham, "Contribution of mitochondria to oxidative stress associated with alcoholic liver disease," Free Radical Biology and Medicine, vol. 32, no. 1, pp. 11-16, 2002.

[63] A. P. Arruda, B. M. Pers, G. Parlakgül, E. Güney, K. Inouye, and G. S. Hotamisligil, "Chronic enrichment of hepatic endoplasmic reticulum-mitochondria contact leads to mitochondrial dysfunction in obesity," Nature Medicine, vol. 20, no. 12, pp. 14271435, 2014. 
[64] F. Nassir and J. A. Ibdah, "Role of mitochondria in nonalcoholic fatty liver disease," International Journal of Molecular Sciences, vol. 15, no. 5, pp. 8713-8742, 2014.

[65] Y. Nakagawa, M. Yoshioka, Y. Abe et al., "Enhancement of liver regeneration by adenosine triphosphate-sensitive $\mathrm{K}+$ channel opener (diazoxide) after partial hepatectomy," Transplantation, vol. 93, no. 11, pp. 1094-1100, 2012.

[66] K. D. Garlid, P. Paucek, V. Yarov-Yarovoy et al., "Cardioprotective effect of diazoxide and its interaction with mitochondrial ATP-sensitive $\mathrm{K}^{+}$channels: possible mechanism of cardioprotection," Circulation Research, vol. 81, no. 6, pp. 1072-1082, 1997.

[67] K. Shimizu, Z. Lacza, N. Rajapakse, T. Horiguchi, J. Snipes, and D. W. Busija, "Mito ${ }_{\text {KATP }}$ opener, diazoxide, reduces neuronal damage after middle cerebral artery occlusion in the rat," American Journal of Physiology-Heart and Circulatory Physiology, vol. 283, no. 3, pp. H1005-H1011, 2002.

[68] R. Rizzuto, D. De Stefani, A. Raffaello, and C. Mammucari, "Mitochondria as sensors and regulators of calcium signalling," Nature Reviews Molecular Cell Biology, vol. 13, no. 9, pp. 566578, 2012.

[69] L. Leanza, L. Biasutto, A. Managò, E. Gulbins, M. Zoratti, and I. Szabò, "Intracellular ion channels and cancer," Frontiers in Physiology, vol. 4, article 227, 2013.

[70] A. Das, C. Pushparaj, J. Herreros et al., "T-type calcium channel blockers inhibit autophagy and promote apoptosis of malignant melanoma cells," Pigment Cell and Melanoma Research, vol. 26, no. 6, pp. 874-885, 2013.

[71] L. Leanza, E. Venturini, S. Kadow, A. Carpinteiro, E. Gulbins, and K. A. Becker, "Targeting a mitochondrial potassium channel to fight cancer," Cell Calcium, vol. 58, no. 1, pp. 131-138, 2015.

[72] L. Leanza, M. Zoratti, E. Gulbins, and I. Szabo, "Mitochondrial ion channels as oncological targets," Oncogene, vol. 33, no. 49, pp. 5569-5581, 2014.

[73] S. M. Madamba, K. N. Damri, L. M. Dejean, and P. M. Peixoto, "Mitochondrial ion channels in cancer transformation," Frontiers in Oncology, vol. 5, article 120, 2015.

[74] WHO, Global Status Report on Alcohol and Health 2014, WHO, Geneva, Switzerland, 2014.

[75] R. Bruha, K. Dvorak, and J. Petrtyl, "Alcoholic liver disease," World Journal of Hepatology, vol. 4, no. 3, pp. 81-90, 2012.

[76] E. Ceni, T. Mello, and A. Galli, "Pathogenesis of alcoholic liver disease: role of oxidative metabolism," World Journal of Gastroenterology, vol. 20, no. 47, pp. 17756-17772, 2014.

[77] B. Gao and R. Bataller, "Alcoholic liver disease: pathogenesis and new therapeutic targets," Gastroenterology, vol. 141, no. 5, pp. 1572-1585, 2011.

[78] A. Gramenzi, F. Caputo, M. Biselli et al., "Review article: Alcoholic liver disease-pathophysiological aspects and risk factors," Alimentary Pharmacology and Therapeutics, vol. 24, no. 8, pp. 1151-1161, 2006.

[79] B. Sid, J. Verrax, and P. B. Calderon, "Role of oxidative stress in the pathogenesis of alcohol-induced liver disease," Free Radical Research, vol. 47, no. 11, pp. 894-904, 2013.

[80] J. Ferlay, I. Soerjomataram, M. Ervik et al., GLOBOCAN 2012 V1.0, Cancer Incidence and Mortality Worldwide: IARC CancerBase No. 11, International Agency for Research on Cancer, Lyon, France, 2013.

[81] E. Albano, "Oxidative mechanisms in the pathogenesis of alcoholic liver disease," Molecular Aspects of Medicine, vol. 29, no. 1-2, pp. 9-16, 2008.
[82] A. Ambade and P. Mandrekar, "Oxidative stress and inflammation: essential partners in alcoholic liver disease," International Journal of Hepatology, vol. 2012, Article ID 853175, 9 pages, 2012.

[83] J. I. Beier and C. J. McClain, "Mechanisms and cell signaling in alcoholic liver disease," Biological Chemistry, vol. 391, no. 11, pp. 1249-1264, 2010.

[84] A. M. Miller, N. Horiguchi, W.-I. Jeong, S. Radaeva, and B. Gao, "Molecular mechanisms of alcoholic liver disease: innate immunity and cytokines," Alcoholism: Clinical and Experimental Research, vol. 35, no. 5, pp. 787-793, 2011.

[85] C. S. Lieber, "Microsomal ethanol-oxidizing system (MEOS): the first 30 years (1968-1998) - a review," Alcoholism: Clinical and Experimental Research, vol. 23, no. 6, pp. 991-1007, 1999.

[86] S. K. Das and D. M. Vasudevan, "Alcohol-induced oxidative stress," Life Sciences, vol. 81, no. 3, pp. 177-187, 2007.

[87] M. Vidali, S. F. Stewart, and E. Albano, "Interplay between oxidative stress and immunity in the progression of alcoholmediated liver injury," Trends in Molecular Medicine, vol. 14, no. 2, pp. 63-71, 2008.

[88] A. Dey and A. I. Cederbaum, "Alcohol and oxidative liver injury," Hepatology, vol. 43, no. 2, supplement 1, pp. S63-S74, 2006.

[89] S. M. Bailey, E. C. Pietsch, and C. C. Cunningham, "Ethanol stimulates the production of reactive oxygen species at mitochondrial complexes I and III," Free Radical Biology and Medicine, vol. 27, no. 7-8, pp. 891-900, 1999.

[90] M. Adachi and H. Ishii, "Role of mitochondria in alcoholic liver injury," Free Radical Biology and Medicine, vol. 32, no. 6, pp. 487491, 2002.

[91] I. Kurose, H. Higuchi, S. Kato et al., "Oxidative stress on mitochondria and cell membrane of cultured rat hepatocytes and perfused liver exposed to ethanol," Gastroenterology, vol. 112, no. 4, pp. 1331-1343, 1997.

[92] M. Yan, P. Zhu, H.-M. Liu, H.-T. Zhang, and L. Liu, "Ethanol induced mitochondria injury and permeability transition pore opening: role of mitochondria in alcoholic liver disease," World Journal of Gastroenterology, vol. 13, no. 16, pp. 2352-2356, 2007.

[93] P. Bernardi, "The mitochondrial permeability transition pore: a mystery solved?” Frontiers in Physiology, vol. 4, article 95, 2013.

[94] P. Bernardi, A. Rasola, M. Forte, and G. Lippe, "The mitochondrial permeability transition pore: channel formation by F-ATP synthase, integration in signal transduction, and role in pathophysiology," Physiological Reviews, vol. 95, no. 4, pp. 11111155, 2015.

[95] P. Bernardi, F. Di Lisa, F. Fogolari, and G. Lippe, "From ATP to PTP and back: a dual function for the mitochondrial ATP synthase," Circulation Research, vol. 116, no. 11, pp. 1850-1862, 2015.

[96] C. Brenner and M. Moulin, "Physiological roles of the permeability transition pore," Circulation Research, vol. 111, no. 9, pp. 1237-1247, 2012.

[97] G. E. N. Kass, M. J. Juedes, and S. Orrenius, "Cyclosporin a protects hepatocytes against prooxidant-induced cell killing. A study on the role of mitochondrial $\mathrm{Ca}^{2+}$ cycling in cytotoxicity," Biochemical Pharmacology, vol. 44, no. 10, pp. 1995-2003, 1992.

[98] M. L. Hautekeete, I. Dodeman, V. Azais-Braesco, K. D. Van Berg, C. Seynaeve, and A. Geerts, "Hepatic stellate cells and liver retinoid content in alcoholic liver disease in humans," Alcoholism: Clinical and Experimental Research, vol. 22, no. 2, pp. 494-500, 1998. 
[99] N. I. Han, K. W. Chung, B. M. Ahn et al., "Ultrastructural changes of hepatic stellate cells in the space of Disse in alcoholic fatty liver," Korean Journal of Internal Medicine, vol. 16, no. 3, pp. 160$166,2001$.

[100] M. Vera and N. Nieto, "Hepatic stellate cells and alcoholic liver disease," Revista Espanola de Enfermedades Digestivas, vol. 98, no. 9, pp. 674-684, 2006.

[101] J.-H. Wang, R. G. Batey, and J. George, "Role of ethanol in the regulation of hepatic stellate cell function," World Journal of Gastroenterology, vol. 12, no. 43, pp. 6926-6932, 2006.

[102] H. Oide and R. G. Thurman, "Hepatic Ito cells contain calcium channels: increases with transforming growth factor- $\beta 1$," Hepatology, vol. 20, no. 4, part 1, pp. 1009-1014, 1994.

[103] T. Itatsu, H. Oide, S. Watanabe, M. Tateyama, R. Ochi, and N. Sato, "Alcohol stimulates the expression of L-type voltage-operated $\mathrm{Ca}^{2+}$ channels in hepatic stellate cells," Biochemical and Biophysical Research Communications, vol. 251, no. 2, pp. 533537, 1998.

[104] J. Krstić, D. Trivanović, S. Mojsilović, and J. F. Santibanez, "Transforming growth factor-beta and oxidative stress interplay: implications in tumorigenesis and cancer progression," Oxidative Medicine and Cellular Longevity, vol. 2015, Article ID 654594, 15 pages, 2015.

[105] C. D. Williams, J. Stengel, M. I. Asike et al., "Prevalence of nonalcoholic fatty liver disease and nonalcoholic steatohepatitis among a largely middle-aged population utilizing ultrasound and liver biopsy: a prospective study," Gastroenterology, vol. 140, no. 1, pp. 124-131, 2011.

[106] C. M. Fielding and P. Angulo, "Hepatic steatosis and steatohepatitis: are they really two distinct entities?" Current Hepatitis Reports, vol. 13, no. 2, pp. 151-158, 2014.

[107] S. Bellentani, F. Scaglioni, M. Marino, and G. Bedogni, "Epidemiology of non-alcoholic fatty liver disease," Digestive Diseases, vol. 28, no. 1, pp. 155-161, 2010.

[108] M. Varela-Rey, N. Embade, U. Ariz, S. C. Lu, J. M. Mato, and M. L. Martínez-Chantar, "Non-alcoholic steatohepatitis and animal models: understanding the human disease," International Journal of Biochemistry and Cell Biology, vol. 41, no. 5, pp. 969976, 2009.

[109] A. Takaki, D. Kawai, and K. Yamamoto, "Multiple hits, including oxidative stress, as pathogenesis and treatment target in non-alcoholic steatohepatitis (NASH)," International Journal of Molecular Sciences, vol. 14, no. 10, pp. 20704-20728, 2013.

[110] C. P. M. S. Oliveira, A. M. M. Coelho, H. V. Barbeiro et al., "Liver mitochondrial dysfunction and oxidative stress in the pathogenesis of experimental nonalcoholic fatty liver disease," Brazilian Journal of Medical and Biological Research, vol. 39, no. 2, pp. 189-194, 2006.

[111] S. K. Das and D. M. Vasudevan, "Monitoring oxidative stress in patients with non-alcoholic and alcoholic liver diseases," Indian Journal of Clinical Biochemistry, vol. 20, no. 2, pp. 24-28, 2005.

[112] A. P. Rolo, J. S. Teodoro, and C. M. Palmeira, "Role of oxidative stress in the pathogenesis of nonalcoholic steatohepatitis," Free Radical Biology and Medicine, vol. 52, no. 1, pp. 59-69, 2012.

[113] C. Grimm, L. M. Holdt, C.-C. Chen et al., "High susceptibility to fatty liver disease in two-pore channel 2-deficient mice," Nature Communications, vol. 5, article 4699, 2014.

[114] H. W. Park, I. A. Semple, I. Jang et al., "Pharmacological correction of obesity-induced autophagy arrest using calcium channel blockers," Nature Communications, vol. 5, article 4834, 2014.
[115] H.-W. Park and J. H. Lee, "Calcium channel blockers as potential therapeutics for obesity-associated autophagy defects and fatty liver pathologies," Autophagy, vol. 10, no. 12, pp. 2385-2386, 2015.

[116] G. Poli, "Pathogenesis of liver fibrosis: role of oxidative stress," Molecular Aspects of Medicine, vol. 21, no. 3, pp. 49-98, 2000.

[117] C. Huang, W. Yu, H. Cui et al., "P2X7 blockade attenuates mouse liver fibrosis," Molecular Medicine Reports, vol. 9, no. 1, pp. 5762, 2014.

[118] R. K. Moreira, "Hepatic stellate cells and liver fibrosis," Archives of Pathology and Laboratory Medicine, vol. 131, no. 11, pp. 17281734, 2007.

[119] J. Jiao, S. L. Friedman, and C. Aloman, "Hepatic fibrosis," Current Opinion in Gastroenterology, vol. 25, no. 3, pp. 223-229, 2009.

[120] A. Casini, E. Ceni, R. Salzano et al., "Neutrophil-derived superoxide anion induces lipid peroxidation and stimulates collagen synthesis in human hepatic stellate cells: role of nitric oxide," Hepatology, vol. 25, no. 2, pp. 361-367, 1997.

[121] P. P. Simeonova, R. M. Gallucci, T. Hulderman et al., "The role of tumor necrosis factor- $\alpha$ in liver toxicity, inflammation, and fibrosis induced by carbon tetrachloride," Toxicology and Applied Pharmacology, vol. 177, no. 2, pp. 112-120, 2001.

[122] V. Ralevic and G. Burnstock, "Receptors for purines and pyrimidines," Pharmacological Reviews, vol. 50, no. 3, pp. 413-492, 1998.

[123] D. Lu and P. A. Insel, "Cellular mechanisms of tissue fibrosis. 6. Purinergic signaling and response in fibroblasts and tissue fibrosis," The American Journal of Physiology-Cell Physiology, vol. 306, no. 9, pp. C779-C788, 2014.

[124] G. Beldi, Y. Wu, X. Sun et al., "Regulated catalysis of extracellular nucleotides by vascular CD39/ENTPD1 is required for liver regeneration," Gastroenterology, vol. 135, no. 5, pp. 1751-1760, 2008.

[125] D. S. Emmett, A. Feranchak, G. Kilic et al., "Characterization of ionotrophic purinergic receptors in hepatocytes," Hepatology, vol. 47, no. 2, pp. 698-705, 2008.

[126] J. A. Dranoff, A. I. Masyuk, E. A. Kruglov, N. F. LaRusso, and M. H. Nathanson, "Polarized expression and function of P2Y ATP receptors in rat bile duct epithelia," American Journal of Physiology_Gastrointestinal and Liver Physiology, vol. 281, no. 4, pp. G1059-G1067, 2001.

[127] N. Minagawa, J. Nagata, K. Shibao et al., "Cyclic AMP regulates bicarbonate secretion in cholangiocytes through release of ATP into bile," Gastroenterology, vol. 133, no. 5, pp. 1592-1602, 2007.

[128] M. N. Jhandier, E. A. Kruglov, É. G. Lavoie, J. Sévigny, and J. A. Dranoff, "Portal fibroblasts regulate the proliferation of bile duct epithelia via expression of NTPDase2," The Journal of Biological Chemistry, vol. 280, no. 24, pp. 22986-22992, 2005.

[129] A. I. Masyuk, S. A. Gradilone, J. M. Banales et al., "Cholangiocyte primary cilia are chemosensory organelles that detect biliary nucleotides via $\mathrm{P}_{2} \mathrm{Y}_{12}$ purinergic receptors," American Journal of Physiology-Gastrointestinal and Liver Physiology, vol. 295, no. 4, pp. G725-G734, 2008.

[130] J. A. Dranoff, M. Ogawa, E. A. Kruglov et al., "Expression of P2Y nucleotide receptors and ectonucleotidases in quiescent and activated rat hepatic stellate cells," American Journal of Physiology-Gastrointestinal and Liver Physiology, vol. 287, no. 2, pp. G417-G424, 2004. 
[131] J. A. Dranoff, E. A. Kruglov, O. Abreu-Lanfranco, T. Nguyen, G. Aurora, and D. Jain, "Prevention of liver fibrosis by the purinoceptor antagonist pyridoxal-phosphate-6-azophenyl-2',4'disulfonate (PPDAS)," In Vivo, vol. 21, no. 6, pp. 957-966, 2007.

[132] A. Surprenant, F. Rassendren, E. Kawashima, R. A. North, and G. Buell, "The cytolytic P2Z receptor for extracellular ATP identified as a P2X receptor (P2X7)," Science, vol. 272, no. 5262, pp. 735-738, 1996.

[133] S. Das, R. K. Seth, A. Kumar et al., "Purinergic receptor $\mathrm{X} 7$ is a key modulator of metabolic oxidative stress-mediated autophagy and inflammation in experimental nonalcoholic steatohepatitis," American Journal of Physiology - Gastrointestinal and Liver Physiology, vol. 305, no. 12, pp. G950-G963, 2013.

[134] J. R. Goree, E. G. Lavoie, M. Fausther, and J. A. Dranoff, “Expression of mediators of purinergic signaling in human liver cell lines," Purinergic Signalling, vol. 10, no. 4, pp. 631-638, 2014.

[135] M. R. Elizondo, B. L. Arduini, J. Paulsen et al., "Defective skeletogenesis with kidney stone formation in dwarf zebrafish mutant for trpm7," Current Biology, vol. 15, no. 7, pp. 667-671, 2005.

[136] L. W. Runnels, L. Yue, and D. E. Clapham, "TRP-PLIK, a bifunctional protein with kinase and ion channel activities," Science, vol. 291, no. 5506, pp. 1043-1047, 2001.

[137] D. H. Lam, C. E. Grant, and C. E. Hill, "Differential expression of TRPM7 in rat hepatoma and embryonic and adult hepatocytes," Canadian Journal of Physiology and Pharmacology, vol. 90, no. 4, pp. 435-444, 2012.

[138] Y. Zhu, R. Men, M. Wen, X. Hu, X. Liu, and L. Yang, “Blockage of TRPM7 channel induces hepatic stellate cell death through endoplasmic reticulum stress-mediated apoptosis," Life Sciences, vol. 94, no. 1, pp. 37-44, 2014.

[139] R. Mishra, V. Rao, R. Ta, N. Shobeiri, and C. E. Hill, " $\mathrm{Mg}^{2+}$ - and MgATP-inhibited and $\mathrm{Ca}^{2+} /$ calmodulin-sensitive TRPM7-like current in hepatoma and hepatocytes," The American Journal of Physiology-Gastrointestinal and Liver Physiology, vol. 297, no. 4, pp. G687-G694, 2009.

[140] G. J. Barritt, J. Chen, and G. Y. Rychkov, " $\mathrm{Ca}^{2+}$-permeable channels in the hepatocyte plasma membrane and their roles in hepatocyte physiology," Biochimica et Biophysica Acta (BBA)Molecular Cell Research, vol. 1783, no. 5, pp. 651-672, 2008.

[141] L. Fang, C. Huang, X. Meng et al., "TGF- $\beta 1$-elevated TRPM7 channel regulates collagen expression in hepatic stellate cells via TGF- $\beta 1 /$ Smad pathway," Toxicology and Applied Pharmacology, vol. 280, no. 2, pp. 335-344, 2014.

[142] L. Fang, S. Zhan, C. Huang et al., “TRPM7 channel regulates PDGF-BB-induced proliferation of hepatic stellate cells via PI3K and ERK pathways," Toxicology and Applied Pharmacology, vol. 272, no. 3, pp. 713-725, 2013.

[143] H. Liu, J. Li, Y. Huang, and C. Huang, "Inhibition of transient receptor potential melastain 7 channel increases HSCs apoptosis induced by TRAIL," Life Sciences, vol. 90, no. 15-16, pp. 612618, 2012.

[144] Y. Songa, L. Zhan, M. Yu et al., "TRPV4 channel inhibits TGF$\beta 1$-induced proliferation of hepatic stellate cells," PLOS ONE, vol. 9, no. 7, Article ID e101179, 2014.

[145] B. H. Bentzen, S.-P. Olesen, L. C. B. Rønn, and M. Grunnet, "BK channel activators and their therapeutic perspectives," Frontiers in Physiology, vol. 5, article 389, 2014.

[146] T. Hoshi, A. Pantazis, and R. Olcese, "Transduction of voltage and $\mathrm{Ca}^{2+}$ signals by Slo1 BK channels," Physiology, vol. 28, no. 3 , pp. 172-189, 2013.
[147] A. Hermann, G. Sitdikova, and T. Weiger, "Oxidative stress and maxi calcium-activated potassium (BK) channels," Biomolecules, vol. 5, no. 3, pp. 1870-1911, 2015.

[148] R. Köhler, B. P. Kaistha, and H. Wulff, "Vascular KCa-channels as therapeutic targets in hypertension and restenosis disease," Expert Opinion on Therapeutic Targets, vol. 14, no. 2, pp. 143155, 2010.

[149] E. A. Ko, J. Han, I. D. Jung, and W. S. Park, "Physiological roles of $\mathrm{K}^{+}$channels in vascular smooth muscle cells," Journal of Smooth Muscle Research, vol. 44, no. 2, pp. 65-81, 2008.

[150] A. Rodríguez-Vilarrupla, M. Graupera, V. Matei et al., "Largeconductance calcium-activated potassium channels modulate vascular tone in experimental cirrhosis," Liver International, vol. 28, no. 4, pp. 566-573, 2008.

[151] X. Gasull, R. Bataller, P. Ginès et al., "Human myofibroblastic hepatic stellate cells express $\mathrm{Ca}^{2+}$-activated $\mathrm{K}^{+}$channels that modulate the effects of endothelin-1 and nitric oxide," Journal of Hepatology, vol. 35, no. 6, pp. 739-748, 2001.

[152] X. D. Tang, M. L. Garcia, S. H. Heinemann, and T. Hoshi, "Reactive oxygen species impair Slol BK channel function by altering cysteine-mediated calcium sensing," Nature Structural and Molecular Biology, vol. 11, no. 2, pp. 171-178, 2004.

[153] T. Stauber, T. Weinert, and T. J. Jentsch, "Cell biology and physiology of CLC chloride channels and transporters," Comprehensive Physiology, vol. 2, no. 3, pp. 1701-1744, 2012.

[154] G. J. M. den Hartog, S. Qi, J. H. O. Van Tilburg, G. H. Koek, and A. Bast, "Superoxide anion radicals activate hepatic stellate cells after entry through chloride channels: a new target in liver fibrosis," European Journal of Pharmacology, vol. 724, no. 1, pp. 140-144, 2014.

[155] B. J. Hawkins, M. Madesh, C. J. Kirkpatrick, and A. B. Fisher, "Superoxide flux in endothelial cells via the chloride channel-3 mediates intracellular signaling," Molecular Biology of the Cell, vol. 18, no. 6, pp. 2002-2012, 2007.

[156] R. E. Lynch and I. Fridovich, "Permeation of the erythrocyte stroma by superoxide radical," The Journal of Biological Chemistry, vol. 253, no. 13, pp. 4697-4699, 1978.

[157] Y. Ikebuchi, N. Masumoto, K. Tasaka et al., "Superoxide anion increases intracellular $\mathrm{pH}$, intracellular free calcium, and arachidonate release in human amnion cells," Journal of Biological Chemistry, vol. 266, no. 20, pp. 13233-13237, 1991.

[158] R. Waldmann, G. Champigny, F. Bassilana, C. Heurteaux, and M. Lazdunski, "A proton-gated cation channel involved in acidsensing," Nature, vol. 386, no. 6621, pp. 173-177, 1997.

[159] Z.-G. Xiong, X.-P. Chu, and R. P. Simon, " $\mathrm{Ca}^{2+}$-permeable acidsensing ion channels and ischemic brain injury," The Journal of Membrane Biology, vol. 209, no. 1, pp. 59-68, 2006.

[160] F.-R. Wu, C.-X. Pan, C. Rong et al., "Inhibition of acid-sensing ion channel la in hepatic stellate cells attenuates PDGF-induced activation of HSCs through MAPK pathway," Molecular and Cellular Biochemistry, vol. 395, no. 1-2, pp. 199-209, 2014.

[161] A. Arzumanyan, H. M. G. P. V. Reis, and M. A. Feitelson, "Pathogenic mechanisms in HBV- and HCV-associated hepatocellular carcinoma," Nature Reviews Cancer, vol. 13, no. 2, pp. 123-135, 2013.

[162] B. Sun and M. Karin, "Inflammation and liver tumorigenesis," Frontiers of Medicine, vol. 7, no. 2, pp. 242-254, 2013.

[163] X.-W. Yang, J.-W. Liu, R.-C. Zhang, Q. Yin, W.-Z. Shen, and J.-L. $\mathrm{Yi}$, "Inhibitory effects of blockage of intermediate conductance $\mathrm{Ca}^{2+}$-activated $\mathrm{K}^{+}$channels on proliferation of hepatocellular carcinoma cells," Journal of Huazhong University of Science and Technology [Medical Sciences], vol. 33, no. 1, pp. 86-89, 2013. 
[164] C. Freise, M. Ruehl, D. Seehofer, J. Hoyer, and R. Somasundaram, "The inhibitor of $\mathrm{Ca}^{2+}$-dependent $\mathrm{K}^{+}$channels TRAM34 blocks growth of hepatocellular carcinoma cells via downregulation of estrogen receptor alpha mRNA and nuclear factor«B," Investigational New Drugs, vol. 31, no. 2, pp. 452-457, 2013.

[165] B. Minguez, V. Tovar, D. Chiang, A. Villanueva, and J. M. Llovet, "Pathogenesis of hepatocellular carcinoma and molecular therapies," Current Opinion in Gastroenterology, vol. 25, no. 3, pp. 186-194, 2009.

[166] W. Lai, S. Chen, H. Wu et al., "PRL-3 promotes the proliferation of LoVo cells via the upregulation of KCNN4 channels," Oncology Reports, vol. 26, no. 4, pp. 909-917, 2011.

[167] M. de Guadalupe Chávez-López, J. I. Pérez-Carreón, V. ZuñigaGarcía et al., "Astemizole-based anticancer therapy for hepatocellular carcinoma (HCC), and Eag1 channels as potential earlystage markers of HCC," Tumor Biology, vol. 36, no. 8, pp. 61496158, 2015.

[168] V. Zúñiga-García, M. de Guadalupe Chávez-López, V. Quintanar-Jurado et al., "Differential expression of ion channels and transporters during hepatocellular carcinoma development," Digestive Diseases and Sciences, vol. 60, no. 8, pp. 2373-2383, 2015.

[169] D. Varela, F. Simon, A. Riveros, F. Jørgensen, and A. Stutzin, "NAD $(\mathrm{P}) \mathrm{H}$ oxidase-derived $\mathrm{H}_{2} \mathrm{O}_{2}$ signals chloride channel activation in cell volume regulation and cell proliferation," The Journal of Biological Chemistry, vol. 279, no. 14, pp. 13301-13304, 2004.

[170] D. Varela, F. Simon, P. Olivero et al., "Activation of $\mathrm{H}_{2} \mathrm{O}_{2}$ induced VSOR Cl${ }^{-}$currents in HTC cells require phospholipase $\mathrm{C} \gamma 1$ phosphorylation and $\mathrm{Ca}^{2+}$ mobilisation," Cellular Physiology and Biochemistry, vol. 20, no. 6, pp. 773-780, 2007.

[171] R.-K. Li, J. Zhang, Y.-H. Zhang, M.-L. Li, M. Wang, and J.-W. Tang, "Chloride intracellular channel 1 is an important factor in the lymphatic metastasis of hepatocarcinoma," Biomedicine and Pharmacotherapy, vol. 66, no. 3, pp. 167-172, 2012.

[172] X. Wei, J. Li, H. Xie et al., "Chloride intracellular channel 1 participates in migration and invasion of hepatocellular carcinoma by targeting maspin," Journal of Gastroenterology and Hepatology, vol. 30, no. 1, pp. 208-216, 2015.

[173] J. Zhang, M. Li, M. Song et al., "Clicl plays a role in mouse hepatocarcinoma via modulating Annexin A7 and Gelsolin in vitro and in vivo," Biomedicine and Pharmacotherapy, vol. 69, pp. 416-419, 2015.

[174] G. Ermak and K. J. A. Davies, "Calcium and oxidative stress: from cell signaling to cell death," Molecular Immunology, vol. 38, no. 10, pp. 713-721, 2002.

[175] W. Huang, C. Lu, Y. Wu, S. Ouyang, and Y. Chen, "T-type calcium channel antagonists, mibefradil and NNC-55-0396 inhibit cell proliferation and induce cell apoptosis in leukemia cell lines," Journal of Experimental \& Clinical Cancer Research, vol. 34, no. 1, p. 54, 2015.

[176] B. Dziegielewska, L. S. Gray, and J. Dziegielewski, “T-type calcium channels blockers as new tools in cancer therapies," Pflugers Archiv European Journal of Physiology, vol. 466, no. 4, pp. 801-810, 2014.

[177] Y. Li, S. Liu, F. Lu et al., "A role of functional T-type Ca2+ channel in hepatocellular carcinoma cell proliferation," Oncology Reports, vol. 22, no. 5, pp. 1229-1235, 2009.

[178] R. Xie, J. Xu, G. Wen et al., "The P2Y2 nucleotide receptor mediates the proliferation and migration of human hepatocellular carcinoma cells induced by ATP," The Journal of Biological Chemistry, vol. 289, no. 27, pp. 19137-19149, 2014.
[179] D. Lavanchy, "The global burden of hepatitis C," Liver International, vol. 29, supplement 1, pp. 74-81, 2009.

[180] S. L. Chen and T. R. Morgan, "The natural history of hepatitis $\mathrm{C}$ virus (HCV) infection," International Journal of Medical Sciences, vol. 3, no. 2, pp. 47-52, 2006.

[181] F. V. Chisari, "Unscrambling hepatitis C virus-host interactions," Nature, vol. 436, no. 7053, pp. 930-932, 2005.

[182] X. Li and S. A. Weinman, "Chloride channels and hepatocellular function: prospects for molecular identification," Annual Review of Physiology, vol. 64, pp. 609-633, 2002.

[183] J. Graf and D. Häussinger, "Ion transport in hepatocytes: mechanisms and correlations to cell volume, hormone actions and metabolism," Journal of Hepatology, vol. 24, supplement 1, pp. 53-77, 1996.

[184] A. Girault and E. Brochiero, "Evidence of $\mathrm{K}^{+}$channel function in epithelial cell migration, proliferation, and repair," American Journal of Physiology: Cell Physiology, vol. 306, no. 4, pp. C307C319, 2014.

[185] H. A. Kolb, "Potassium channels in excitable and non-excitable cells," Reviews of Physiology Biochemistry and Pharmacology, vol. 115, pp. 51-91, 1990.

[186] Y. Amako, Z. Igloi, J. Mankouri et al., "Hepatitis C virus NS5A inhibits mixed lineage kinase 3 to block apoptosis," The Journal of Biological Chemistry, vol. 288, no. 34, pp. 24753-24763, 2013.

[187] Z. Igloi, B. Mohl, J. D. Lippiat, M. Harris, J. Mankouri, and M. S. Diamond, "Requirement for chloride channel function during the hepatitis C virus life cycle," Journal of Virology, vol. 89, no. 7, pp. 4023-4029, 2015.

[188] M. B. Zeisel, H. Barth, C. Schuster, and T. F. Baumert, "Hepatitis $\mathrm{C}$ virus entry: molecular mechanisms and targets for antiviral therapy," Frontiers in Bioscience, vol. 14, no. 9, pp. 3274-3285, 2009.

[189] J. G. Moreland, A. P. Davis, G. Bailey, W. M. Nauseef, and F. S. Lamb, "Anion channels, including ClC-3, are required for normal neutrophil oxidative function, phagocytosis, and transendothelial migration," Journal of Biological Chemistry, vol. 281, no. 18, pp. 12277-12288, 2006.

[190] S. Thevananther, H. Sun, D. Li et al., "Extracellular ATP activates c-jun N-terminal kinase signaling and cell cycle progression in hepatocytes," Hepatology, vol. 39, no. 2, pp. 393-402, 2004.

[191] S. Manzoor, M. Idrees, J. Ashraf et al., "Identification of ionotrophic purinergic receptors in Huh-7 cells and their response towards structural proteins of HCV genotype 3a," Virology Journal, vol. 8, article 431, 2011.

[192] V. C. Minguetti-Câmara, J. Constantin, F. Suzuki-Kemmelmeier, E. L. Ishii-Iwamoto, and A. Bracht, "Hepatic heterogeneity in the response to ATP studied in the bivascularly perfused rat liver," Molecular and Cellular Biochemistry, vol. 179, no. 1-2, pp. 35-48, 1998.

[193] A. M. Waszkielewicz, A. Gunia, N. Szkaradek, K. Sloczynska, S. Krupinska, and H. Marona, "Ion channels as drug targets in central nervous system disorders," Current Medicinal Chemistry, vol. 20, no. 10, pp. 1241-1285, 2013.

[194] R. Köhling, "Voltage-gated sodium channels in epilepsy," Epilepsia, vol. 43, no. 11, pp. 1278-1295, 2002.

[195] W. A. Catterall, A. L. Goldin, and S. G. Waxman, "International Union of Pharmacology. XLVII. Nomenclature and structurefunction relationships of voltage-gated sodium channels," Pharmacological Reviews, vol. 57, no. 4, pp. 397-409, 2005. 
[196] K. Kamiya, M. Kaneda, T. Sugawara et al., "A nonsense mutation of the sodium channel gene SCN2A in a patient with intractable epilepsy and mental decline," Journal of Neuroscience, vol. 24, no. 11, pp. 2690-2698, 2004.

[197] A. M. Rush, S. D. Dib-Hajj, and S. G. Waxman, "Electrophysiological properties of two axonal sodium channels, Nav1.2 and Navl.6, expressed in mouse spinal sensory neurones," Journal of Physiology, vol. 564, part 3, pp. 803-815, 2005.

[198] J. D. England, L. T. Happel, D. G. Kline et al., "Sodium channel accumulation in humans with painful neuromas," Neurology, vol. 47, no. 1, pp. 272-276, 1996.

[199] J. G. J. Hoeijmakers, C. G. Faber, I. S. J. Merkies, and S. G. Waxman, "Painful peripheral neuropathy and sodium channel mutations," Neuroscience Letters, vol. 596, pp. 51-59, 2015.

[200] E. M. Nagasako, A. L. Oaklander, and R. H. Dworkin, "Congenital insensitivity to pain: an update," Pain, vol. 101, no. 3, pp. 213-219, 2003.

[201] S. D. Dib-Hajj, A. M. Binshtok, T. R. Cummins, M. F. Jarvis, T. Samad, and K. Zimmermann, "Voltage-gated sodium channels in pain states: role in pathophysiology and targets for treatment," Brain Research Reviews, vol. 60, no. 1, pp. 65-83, 2009.

[202] J. Huang, C. Han, M. Estacion et al., "Gain-of-function mutations in sodium channel $\mathrm{Na}(\mathrm{v}) 1.9$ in painful neuropathy," Brain, vol. 137, part 6, pp. 1627-1642, 2014.

[203] H. Ye, S. Jalini, S. Mylvaganam, and P. Carlen, "Activation of large-conductance $\mathrm{Ca}^{2+}$-activated $\mathrm{K}^{+}$channels depresses basal synaptic transmission in the hippocampal CA1 area in APP (swe/ind) TgCRND8 mice," Neurobiology of Aging, vol. 31, no. 4, pp. 591-604, 2010.

[204] C. Huang, S. Shen, Q. Ma et al., "Blockade of KCa3.1 ameliorates renal fibrosis through the tgf- $\beta 1 /$ smad pathway in diabetic mice," Diabetes, vol. 62, no. 8, pp. 2923-2934, 2013.

[205] T. T. Chen, T. L. Klassen, A. M. Goldman, C. Marini, R. Guerrini, and J. L. Noebels, "Novel brain expression of ClC-1 chloride channels and enrichment of CLCN1 variants in epilepsy;" Neurology, vol. 80, no. 12, pp. 1078-1085, 2013.

[206] C. Jin, Q.-H. Ye, F.-L. Yuan et al., "Involvement of acidsensing ion channel $1 \alpha$ in hepatic carcinoma cell migration and invasion," Tumor Biology, vol. 36, no. 6, pp. 4309-4317, 2015.

[207] R.-H. Du, J. Tan, N. Yan et al., "Kir6.2 knockout aggravates lipopolysaccharide-induced mouse liver injury via enhancing NLRP3 inflammasome activation," Journal of Gastroenterology, vol. 49, no. 4, pp. 727-736, 2014.

[208] E. Kheradpezhouh, L. Ma, A. Morphett, G. J. Barritt, and G. Y. Rychkov, "TRPM2 channels mediate acetaminophen-induced liver damage," Proceedings of the National Academy of Sciences of the United States of America, vol. 111, no. 8, pp. 3176-3181, 2014.

[209] M. Adachi, H. Higuchi, S. Miura et al., "Bax interacts with the voltage-dependent anion channel and mediates ethanolinduced apoptosis in rat hepatocytes," American Journal of Physiology: Gastrointestinal and Liver Physiology, vol. 287, no. 3, pp. G695-G705, 2004. 


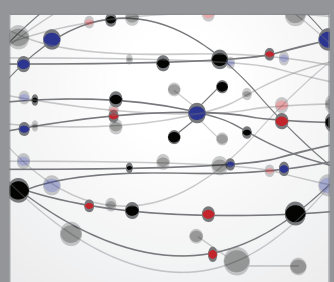

The Scientific World Journal
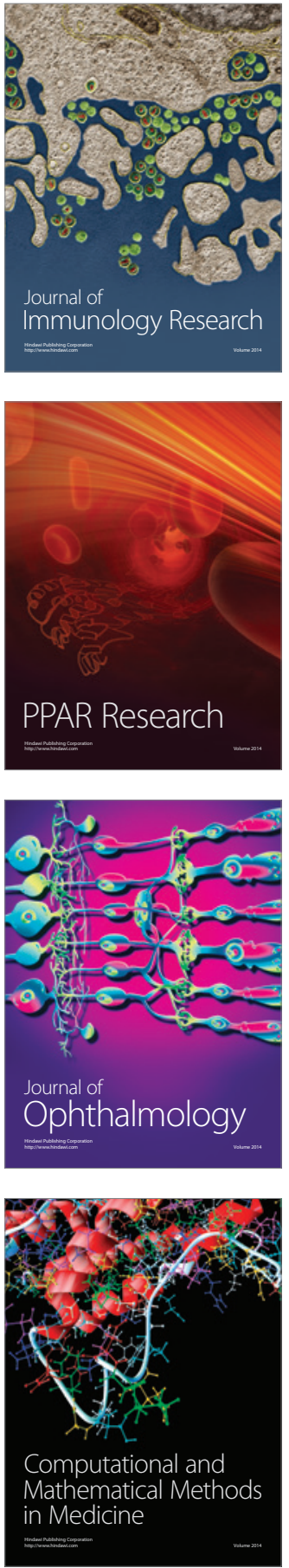

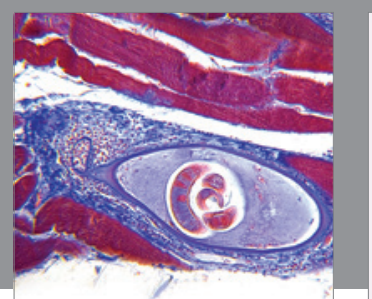

Gastroenterology Research and Practice

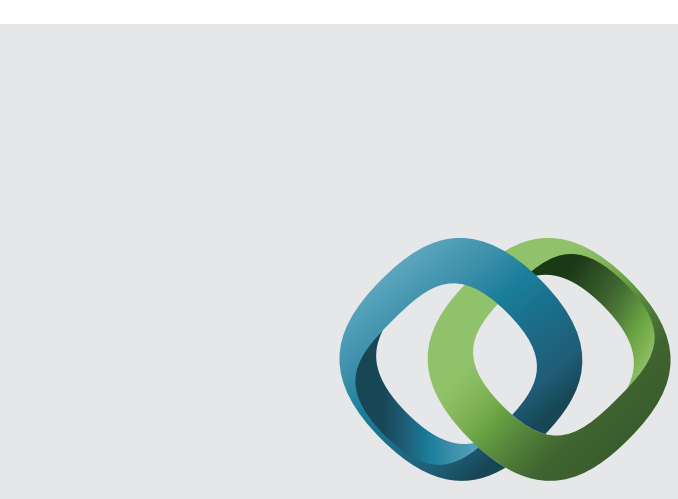

\section{Hindawi}

Submit your manuscripts at

http://www.hindawi.com
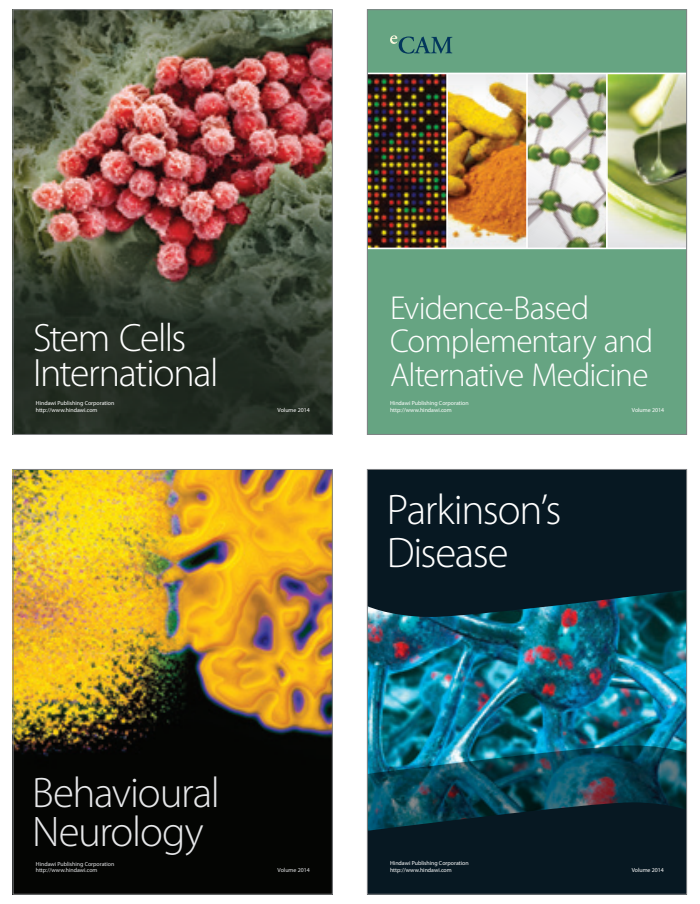
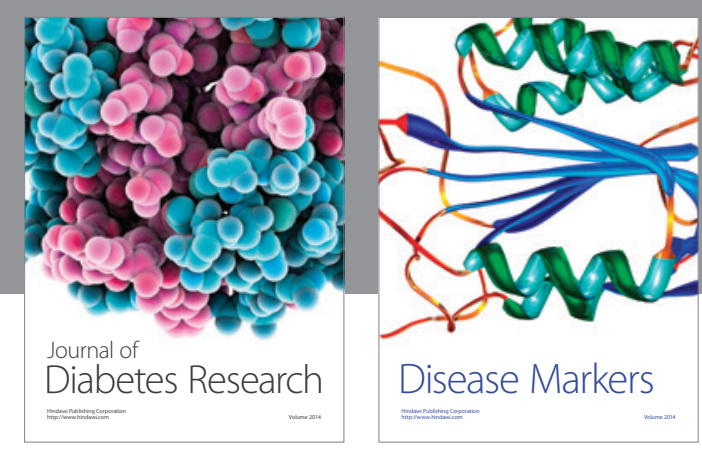

Disease Markers
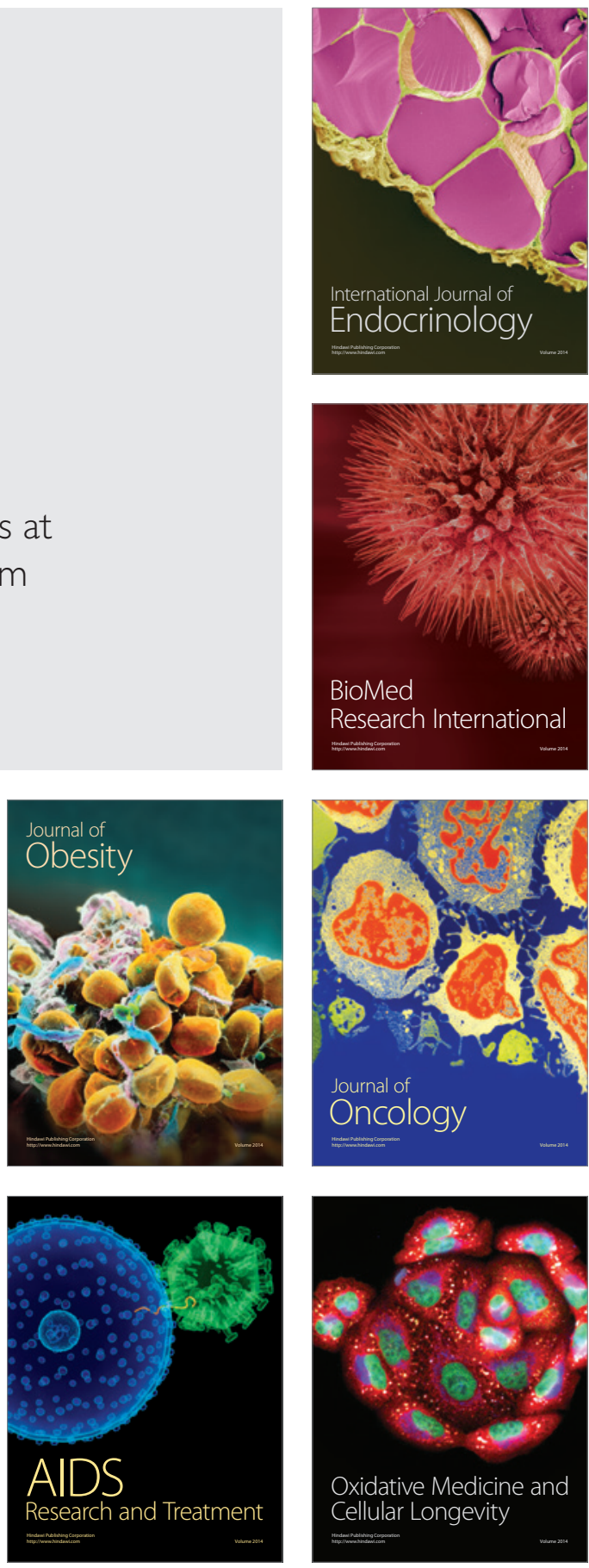